\title{
Hydroboration of Methyl Esters of Fatty Acids
}

\author{
Ali Mcheik, \\ Akram Hijazi, \\ Hicham Diab, \\ Ahmad Shamseddine, \\ Doctoral School of Science and Technology, \\ Research Platform for Environmental Science (PRASE), \\ Lebanese University, Lebanon
}

\begin{abstract}
Hydroboration addition reactions of a boron atom, and hydrogen over unsaturated, have been widely studied. They have excellent access routes to organoborans which have proven to be a very useful synthetic intermediate (Brown et al.; Matteson, 1987; Smith, 1994). The bill might be on one or other of the two carbons of the unsaturation. It is carried out preferentially along the least congested carbon (anti-Markownikov addition). This regioselectivity can be changed against steric effects (Brown \& Zweifel, 1960; Brown \& Sharp, 1968; Brown et al., 1974). The existence of two active sites in methyl esters of fatty acids, FAME: the carbon-carbon unsaturation and the ester, make their hydroboration reactions more difficult to achieve. However, it has been demonstrated that reducing the ester groups is much slower than that of olefins (Brown \& Keblys, 1964). By using suitable operating conditions, it is possible to limit this secondary reaction and to obtain a selective reaction of carboncarbon double bond (Fore \& Bickford, 1959). Others have protecting ester function by a silyl group in order to have a single reactive site (Kabalka \& Bierer, 1989).
\end{abstract}

Keywords: Hydroboration, organoborans, olefins, oleate

\section{Introduction}

Consequently, we develop these hydroboration reactions of three methyl esters of fatty acids: 1) Methyl undec-10 enoate having a terminal double bond: $\mathrm{CH}_{2}=\mathrm{CH}-\left(\mathrm{CH}_{2}\right)_{8}-\mathrm{COOCH}_{3}$. 2) Methyloleate with an internal double bond: $\mathrm{CH}_{3}-\left(\mathrm{CH}_{2}\right)_{7} \mathrm{CH}=\mathrm{CH}\left(\mathrm{CH}_{2}\right)_{7} \mathrm{COOCH}_{3}$. 3) Methyl linoleate with two internal double bonds $\mathrm{CH}_{3}-\left(\mathrm{CH}_{2}\right)_{4}-\mathrm{CH}=\mathrm{CH}-\mathrm{CH}_{2}=\mathrm{CH}-\left(\mathrm{CH}_{2}\right)_{7} \mathrm{COOCH}_{3}$. 
Additionally, we made use of Brown's reaction (Brown et al., 1972). It is mainly quantitative but proceeds without isomerization and with complete retention of configuration. It is a method that is very effective to transform ethylene to alcohol, with the opportunity to study the organoborane through the structure from the isolated alcohol (regioselectivity of hydroboration reaction) (Allinger et al., 1983).

In a first step, to optimize this hydroboration reaction, methyl undec10-enoate has an active double bond. Thus, we selected three hydroborating agents: borane dimethyl sulfide (BMS), the thexylborane (Brown \& Klender, 1962), and the 9-bora [3.3.1] bicyclononane (BBN). The first two is for their ease of use, while the latter is for its greater steric type.

\section{Results and Discussion}

By adding the borane to a solution of undec-10-enoate methyl, we varied the stoichiometry of the reaction, the temperature, and the solvent (Table 1). In the case of BMS, whatever the operating conditions used, analysis by Proton NMR shows the disappearance of the ethylene protons. Thus, this confirms the complete hydroboration of the double bond (Eq. 1).

$$
\begin{aligned}
& (3-\mathrm{x}) \mathrm{CH}_{2}=\mathrm{CH}-\left(\mathrm{CH}_{2}\right)_{8}-\mathrm{COOH}_{3} \stackrel{\mathrm{BMS}}{\longrightarrow} \mathrm{H}_{\mathrm{x}} \mathrm{B}\left(-\mathrm{CH}_{2}-\left(\mathrm{CH}_{2}\right)_{9}-\mathrm{COOCH}_{3}\right)_{3-\mathrm{x}} \quad \text { eq. } 1
\end{aligned}
$$

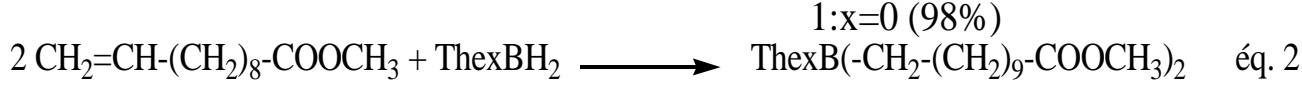

$$
\begin{aligned}
& 2(84 \%)
\end{aligned}
$$

Proton NMR showed the presence of a single isomer with features triplets at $0.79 \mathrm{ppm}$ for product 1 and $1.11 \mathrm{ppm}$ for the product 2 attributed to the $\mathrm{CH}_{2} \mathrm{~B}$ group. Carbon NMR confirmed these results with the presence a new $\mathrm{CH}_{2} \mathrm{~B}$ signal at 22.68 ppm (Ghebreyessus \& Angelici, 2006).

For several peaks at 18.82, 37.04, 55.96, and 92.88 ppm in BoronNMR for undec-10-enoate/BMS (entrance 4), these signals correspond to boranes mono-, di- and tri (Brown et al., 1972). For BBN, the hydroboration reaction is not complete. However, it remains about $15 \%$ of the same starting material due to the steric type of the borane (Eq. 3).

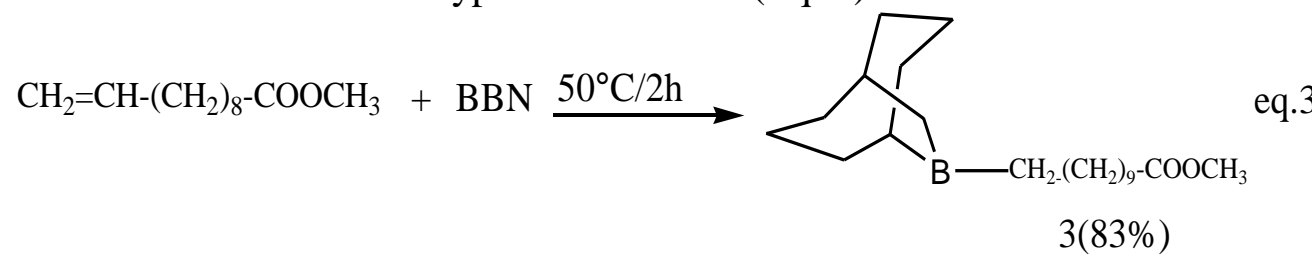

The reaction mixture was treated with hydrogen peroxide in alkaline medium (Eq. 4). In some cases, we observed the formation of the diol due to the reaction of reducing the carbonyl group of the ester function. 


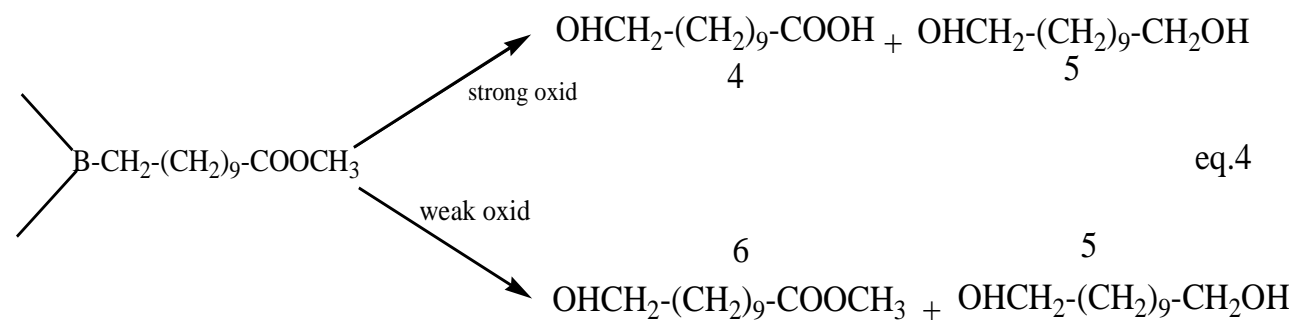

Strong oxidation: hydrogen peroxide (35\%) and $\mathrm{NaOH}(40 \%)$ in THF; weak oxidation: hydrogen peroxide $(13.7 \%)$ and $\mathrm{NaOH}(1 \mathrm{M})$ at room temperature.

The addition of a stoichiometric amount of BMS leads to a mixture of hydroxy acid and diol in percentages of $72 \%$ and $28 \%$ (entrance 2). The use of two equivalents of undec-10-enoate improves the percentage of hydroxy acid $90 \%$ (entrance 3 ). With regards to three equivalents of undec-10-enoate methyl, only hydroxyl acid was obtained (entrance 4). Three equivalents of BMS for one equivalent of undec-10-enoate methyl gives $89 \%$ diol (entrance 5). Therefore, it appears that stoichiometry plays an important role in the case of BMS.

However, by reversing the proportions (entrance 4 and 5), we get either selectively the hydroxyacid 4 or diol 5 . To confirm the reduction of the ester function, we performed a test with a saturated ester: Methyl undecanoate. $\mathrm{CH}_{3}-\left(\mathrm{CH}_{2}\right)_{9}-\mathrm{COOCH}_{3} \frac{1) \mathrm{BMS}}{2) \mathrm{H}_{2} \mathrm{O}_{2} / \mathrm{NaOH}} \mathrm{CH}_{3}-\left(\mathrm{CH}_{2}\right)_{9}-\mathrm{CH}_{2}-\mathrm{OH} \quad$ eq.5

$7(42 \%)$

\begin{tabular}{|c|c|c|c|c|c|}
\hline Entrance & Reactive & Borane & Reactive/borane & $\begin{array}{l}\mathrm{T}^{\circ} \mathrm{C} / \\
\text { solvent }\end{array}$ & $\begin{array}{c}\text { Products } \\
\%\end{array}$ \\
\hline 1 & $\begin{array}{l}\text { Undécanoate } \\
\text { de méthyle }\end{array}$ & BMS & $1 / 1$ & $\begin{array}{c}25^{\circ} \mathrm{C} / \\
\mathrm{THF}\end{array}$ & $7: 42 \% *$ \\
\hline 2 & $\begin{array}{l}\text { Undécanoate } \\
\text { de méthyle }\end{array}$ & BMS & $1 / 1$ & $\begin{array}{c}25^{\circ} \mathrm{C} / \\
\mathrm{THF}\end{array}$ & $\begin{array}{c}4: 72 \% * \\
5: \\
28 \% *\end{array}$ \\
\hline 3 & $\begin{array}{l}\text { Undécanoate } \\
\text { de méthyle }\end{array}$ & $\overline{B M S}$ & $2 / 1$ & $\begin{array}{c}25^{\circ} \mathrm{C} / \\
\mathrm{THF}\end{array}$ & $\begin{array}{l}4: 90 \% * \\
5: 10 \% *\end{array}$ \\
\hline 4 & $\begin{array}{l}\text { Undécanoate } \\
\text { de méthyle }\end{array}$ & BMS & $3 / 1$ & $\begin{array}{c}25^{\circ} \mathrm{C} / \\
\mathrm{THF}\end{array}$ & $\begin{array}{c}4: 100 \% \\
* *\end{array}$ \\
\hline 5 & $\begin{array}{l}\text { Undécanoate } \\
\text { de méthyle }\end{array}$ & BMS & $1 / 3$ & $\begin{array}{c}25^{\circ} \mathrm{C} / \\
\mathrm{THF}\end{array}$ & $\begin{array}{l}4: 11 \% * \\
5: 89 \% *\end{array}$ \\
\hline 6 & $\begin{array}{l}\text { Undécanoate } \\
\text { de méthyle }\end{array}$ & BMS & $3 / 1$ & $\begin{array}{c}25^{\circ} \mathrm{C} / \\
\mathrm{THF}\end{array}$ & $\begin{array}{l}\text { 6: } 65 \% * * \\
5: 35 \% *\end{array}$ \\
\hline 7 & $\begin{array}{l}\text { Undécanoate } \\
\text { de méthyle }\end{array}$ & BMS & $2 / 1$ & $\begin{array}{c}25^{\circ} \mathrm{C} / \\
\mathrm{THF} \\
\end{array}$ & $\begin{array}{c}\text { 6: } 55 \% * * \\
5: 45 \% * \\
\end{array}$ \\
\hline 8 & $\begin{array}{l}\text { Undécanoate } \\
\text { de méthyle }\end{array}$ & BMS & $1 / 1$ & $\begin{array}{l}-5^{\circ} \mathrm{C} / \\
\mathrm{THF}\end{array}$ & $\begin{array}{l}\text { 4: } 80 \% * \\
5: 20 \% *\end{array}$ \\
\hline
\end{tabular}




\begin{tabular}{|c|c|c|c|c|c|}
\hline 9 & $\begin{array}{c}\text { Undécanoate } \\
\text { de méthyle }\end{array}$ & BMS & $1 / 1$ & $\begin{array}{c}25^{\circ} \mathrm{C} / \\
\mathrm{THF}\end{array}$ & $\begin{array}{c}4: 34 \% * \\
5: 66 \% *\end{array}$ \\
\hline 10 & $\begin{array}{c}\text { Undécanoate } \\
\text { de méthyle }\end{array}$ & BBN & $1 / 1$ & $\begin{array}{c}50^{\circ} \mathrm{C} / \\
\mathrm{THF}\end{array}$ & $4: 83 \%^{*}$ \\
\hline 11 & $\begin{array}{c}\text { Chlorure d } \\
\text { Undécanyle }\end{array}$ & BMS & $1 / 1$ & $\begin{array}{c}25^{\circ} \mathrm{C} / \\
\mathrm{THF}\end{array}$ & $4: 98 \% *$ \\
& & & $1 / 1$ & $50{ }^{\circ} \mathrm{C} /$ & $4: 83 \% *$ \\
& $\begin{array}{c}\text { Chlorure d } \\
\text { Undécanyle }\end{array}$ & BBN & & 12 & \\
\hline
\end{tabular}

Table 1. Influence of stoichiometry, temperature, and solvent on the reaction of hydroboration

The percentage of hydroxy ester decrease (entry 6 and 7) after oxidation in fresh conditions. Indeed, the hydroboration reaction at low temperature does not prevent the reduction of the ester function. Subsequently, small decrease in the percentage of diol was formed (entrance 8). Furthermore, the solvent plays an important role, like apolar solvent such as toluene can reverse percentages of hydroxy acid and diol (entrance 9). These early results show the importance of the operating conditions in these hydroboration reactions and especially that of the stoichiometry.

The addition of a stoichiometric amount of BMS to a solution undec 10-enoic acid in THF results in the instantaneous formation of an insoluble polymer (Lane, 1976). That is probably due to the acid function of reduction reaction that is much more reactive than the carbon-carbon unsaturation.

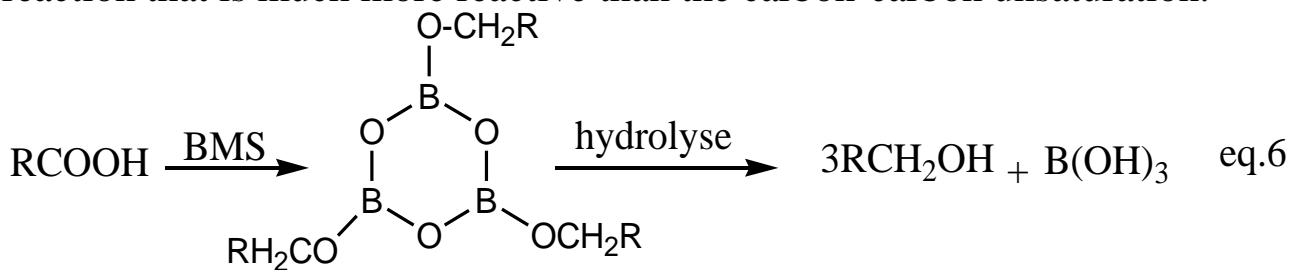

In the case of chloride undec-10-enoyl, the carbonyl group is less reactive with hydroborating agent. Therefore, the reaction with one equivalent of BMS gives, after oxidation, the hydroxy acid 4 and traces of the diol (entrance11) (eq. 7).

$$
\mathrm{CH}_{2}=\mathrm{CH}-\left(\mathrm{CH}_{2}\right)_{8}-\mathrm{COCl}+\mathrm{BMS} \stackrel{25^{\circ} \mathrm{C} / 3 \mathrm{~h} \longrightarrow}{\longrightarrow} \underset{\text { oxidation }}{\stackrel{\mathrm{BH}_{2} \mathrm{CH}_{2}-\mathrm{CH}_{2}-\left(\mathrm{CH}_{2}\right)_{8}-\mathrm{COCl}}{8(94 \%)}} \begin{array}{r}
8 \\
\mathrm{HOCH}_{2}-\mathrm{CH}_{2}-\left(\mathrm{CH}_{2}\right)_{8}-\mathrm{COOH} \quad 4
\end{array}
$$

For $\mathrm{BBN}$, as we have already observed for undec-10-enoate, the hydroboration reaction is not complete (83\%) (Entrance 12). Nevertheless, after oxidation, the hydroxy acid was obtained (Eq. 8). 


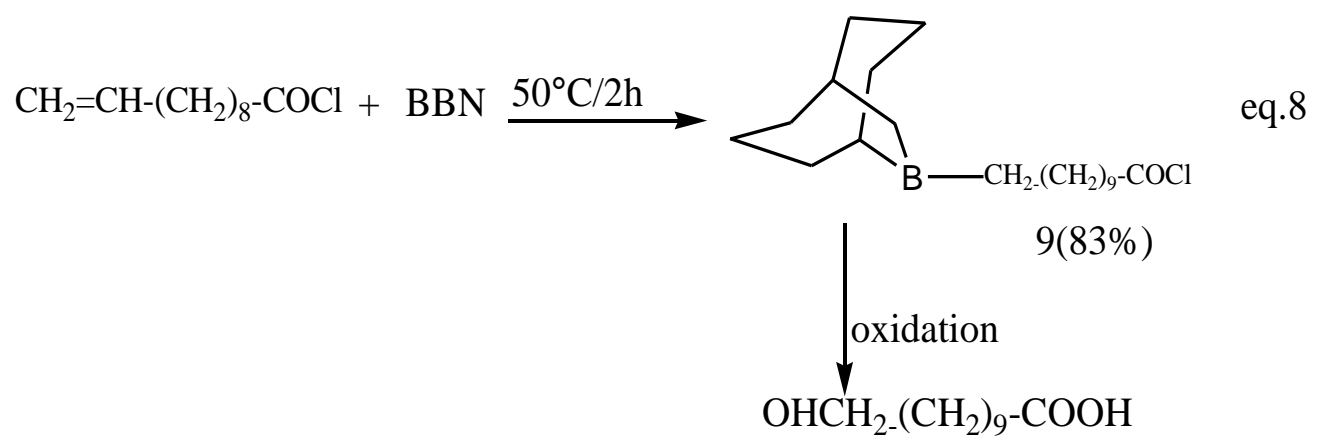

NMR of proton and carbon, in case of $\mathrm{CH}_{2} \mathrm{~B}$ group signals, is at 0.85 ppm and $22.68 \mathrm{ppm}$ respectively, and the case of organoborane is 8 . IR, (NCO) band is at $1712 \mathrm{~cm}^{-1}$ characteristic of chloride acid.

Finally, we tested the hydroboration reaction on the N-phénylundéc10- enamide. The latter was prepared by the action of aniline on undec-10enoate methyl at $200^{\circ} \mathrm{C}$ (Vig et al., 1980). After 24 hours of reaction at this temperature, it was isolated with good yield (72\%) as a white powder (Eq. 9).

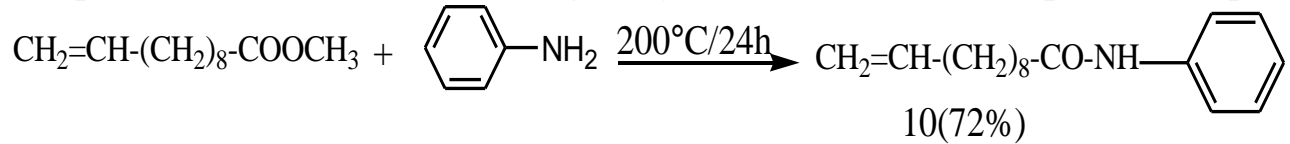

eq. 9

Using the operating conditions that gave the best result for the undec Methyl 10-enoate (Table 1 entrance 4), the action of BMS has enabled us to access a new borane in powder form (eq. 10).

We observed in proton NMR that the signal $\mathrm{CH}_{2}-\mathrm{B}$ group at $0.81 \mathrm{ppm}$ and in carbon NMR was at $22.70 \mathrm{ppm}$. This borane seems to be particularly stable. However, the NMR ${ }^{11} \mathrm{~B}$ spectrum indicates the presence of a one signal at $6.80 \mathrm{ppm}$.

$3 \mathrm{CH}_{2}=\mathrm{CH}-\left(\mathrm{CH}_{2}\right)_{8}-\mathrm{CONHPh}+\mathrm{BMS} \stackrel{25^{\circ} \mathrm{C} / 3 \mathrm{~h}}{\longrightarrow} \mathrm{B}\left(-\mathrm{CH}_{2}-\left(\mathrm{CH}_{2}\right)_{8}-\mathrm{CH}_{2}-\mathrm{CONHPh}\right)_{3} \quad$ eq.10

\section{$11(98 \%)$}

A total hydroboration of double bond for amide 10 at room temperature gives the organoborane 12 as a white gel (eq. 11).

$2 \mathrm{CH}_{2}=\mathrm{CH}-\left(\mathrm{CH}_{2}\right)_{8} \mathrm{CONHPh}+\mathrm{ThexBH} 2 \stackrel{25^{\circ} \mathrm{C} / 3 \mathrm{~h}}{\longrightarrow}$ ThexB(- $\left.-\mathrm{CH}_{2}-\left(\mathrm{CH}_{2}\right)_{8}-\mathrm{CH}_{2}-\mathrm{CONHPh}\right)_{2}$ eq. 11

$$
12(75 \%)
$$

The hydroboration reaction of methyl oleate with BMS (Mole for mole or excess oleate), therefore, complete reaction after only three hours with magnetic stirring at room temperature using THF as solvent (eq. 12). 


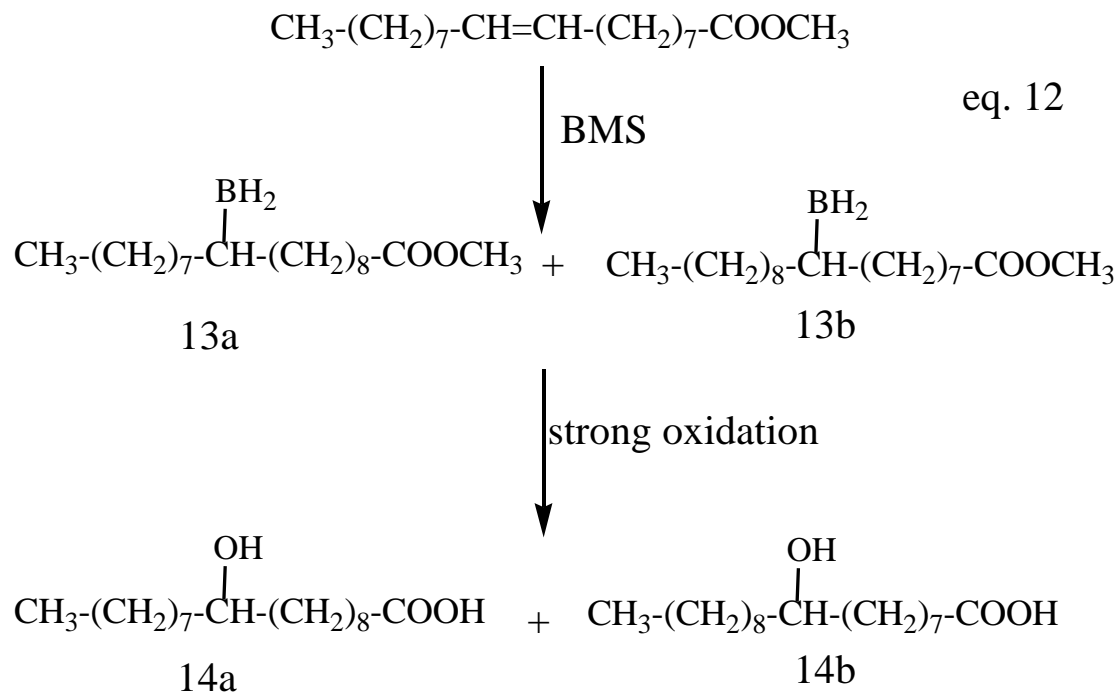

After oxidation with hydrogen peroxide in alkaline medium, the NMR carbon analysis shows the presence of two signals group at 72.07 and 72.09 ppm of $\mathrm{CH}-\mathrm{OH}$ and two carbonyl signals (CO) at 179.41 and $179.50 \mathrm{ppm}$, respectively. In mass spectrometry, we find the characteristic fragments $[\mathrm{HO}$ $\left.=\mathrm{CH}\left(\mathrm{CH}_{2}\right)_{7}-\mathrm{COOH}\right]^{+}(\mathrm{C} 9)$ of mass $173 \mathrm{amu}$ and $\left[\mathrm{HO}=\mathrm{CH}-\left(\mathrm{CH}_{2}\right)_{8}-\mathrm{COOH}\right]$ $+(\mathrm{C} 10)$ of mass $187 \mathrm{amu}$.

Furthermore, we made use of high-performance liquid chromatography (HPLC) to calculate the \%. These hydroxyacides transforms to hydroxyesters after esterification reaction (eq. 13).

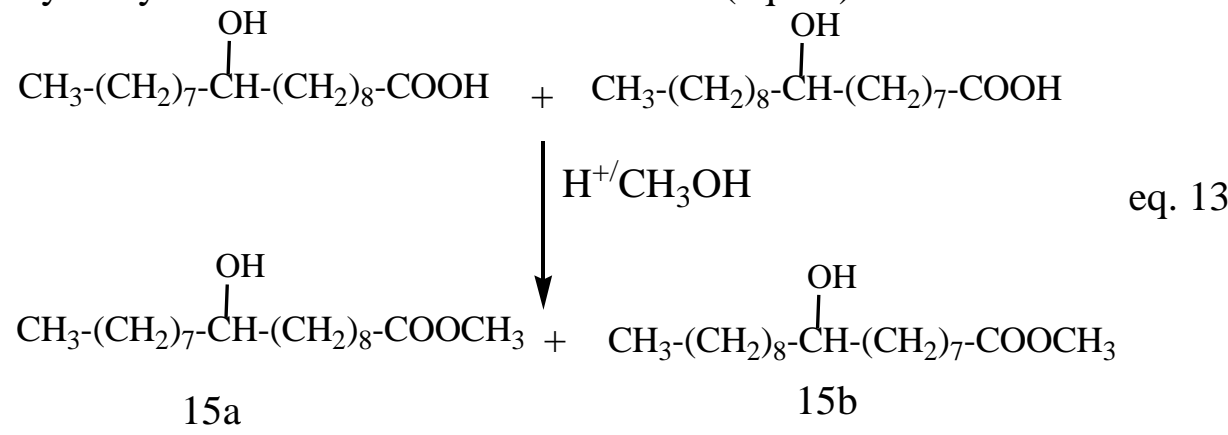

We observe the presence of two signals (OMe) at 3.61 and $3.62 \mathrm{ppm}$ for $15 \mathrm{a}$ and $15 \mathrm{~b}$ based on the data in the literature (Tulloch, 1966) on proton NMR. In mass spectrometry, we find the characteristic fragments $[\mathrm{HO}=\mathrm{CH}-$ $\left.\left(\mathrm{CH}_{2}\right)_{7} \mathrm{COOCH}_{3}\right]^{+}(\mathrm{C} 9)$ of mass $187 \mathrm{amu}$ and $\left[\mathrm{HO}=\mathrm{CH}-\left(\mathrm{CH}_{2}\right)_{8}-\mathrm{COOCH}_{3}\right]^{+}$ (C10) mass $201 \mathrm{amu}$.

Methyl linoleate with two internal double bonds, after hydroboration by BMS, produces four isomers of dibora methyl octadecanoate (eq. 14). 


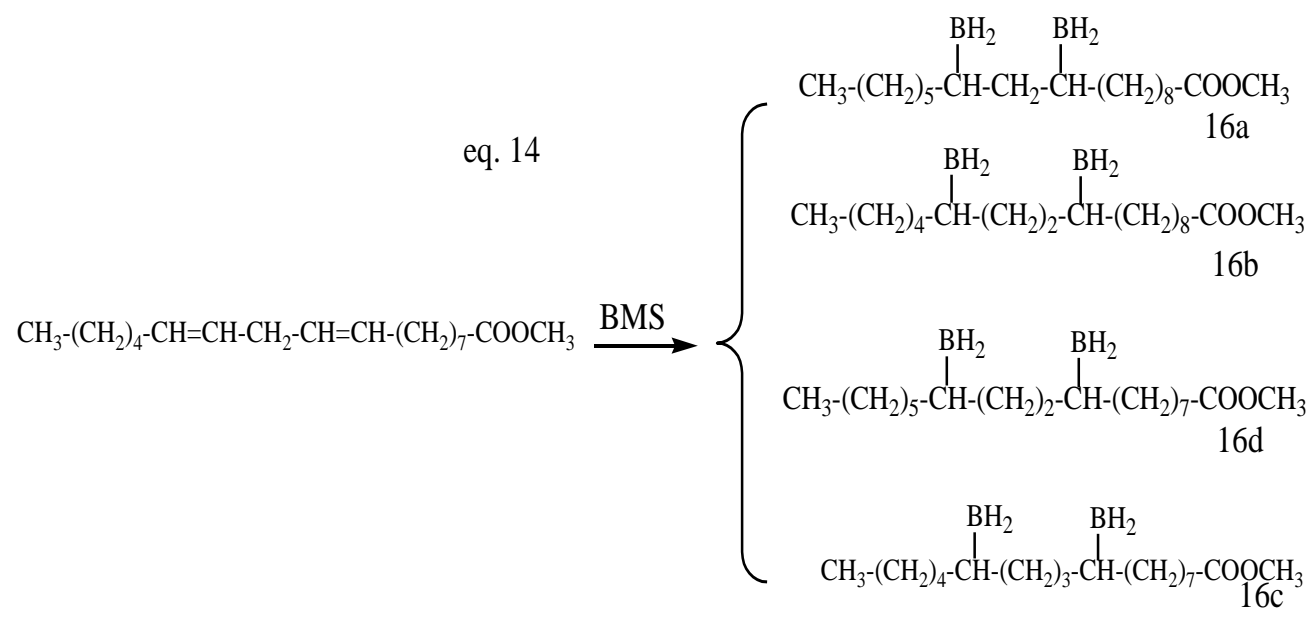

The mixture was oxidized with hydrogen peroxide in alkaline medium (Eq. 15) knowing that this method retains the regioselectivity and proceeds with complete retention of configuration.

$$
\begin{aligned}
& \begin{array}{cc}
\mathrm{BH}_{2} & \mathrm{BH}_{2} \\
\mathrm{CH}_{3}-\left(\mathrm{CH}_{2}\right)_{5}-\mathrm{CH}-\mathrm{CH}_{2}-\mathrm{CH}-\left(\mathrm{CH}_{2}\right)_{8}-\mathrm{COOCH}_{3}
\end{array} \\
& \begin{array}{cc}
\mathrm{BH}_{2} & \stackrel{\mathrm{BH}_{2}}{\mathrm{~L}} \\
\mathrm{CH}_{3}-\left(\mathrm{CH}_{2}\right)_{4}-\mathrm{CH}-\left(\mathrm{CH}_{2}\right)_{2}-\mathrm{CH}-\left(\mathrm{CH}_{2}\right)_{8}-\mathrm{COOCH}_{3}
\end{array} \\
& \begin{array}{cc}
\mathrm{BH}_{2} & \stackrel{\mathrm{BH}_{2}}{!} \\
\mathrm{CH}_{3}-\left(\mathrm{CH}_{2}\right)_{5}-\mathrm{CH}-\left(\mathrm{CH}_{2}\right)_{2}-\mathrm{CH}-\left(\mathrm{CH}_{2}\right)_{7}-\mathrm{COOCH}_{3}
\end{array} \\
& \begin{array}{cc}
\mathrm{BH}_{2} & \mathrm{BH}_{2} \\
\mathrm{CH}_{3}-\left(\mathrm{CH}_{2}\right)_{4}-\mathrm{CH}-\left(\mathrm{CH}_{2}\right)_{3}-\mathrm{CH}-\left(\mathrm{CH}_{2}\right)_{7}-\mathrm{COOCH}_{3}
\end{array}
\end{aligned}
$$

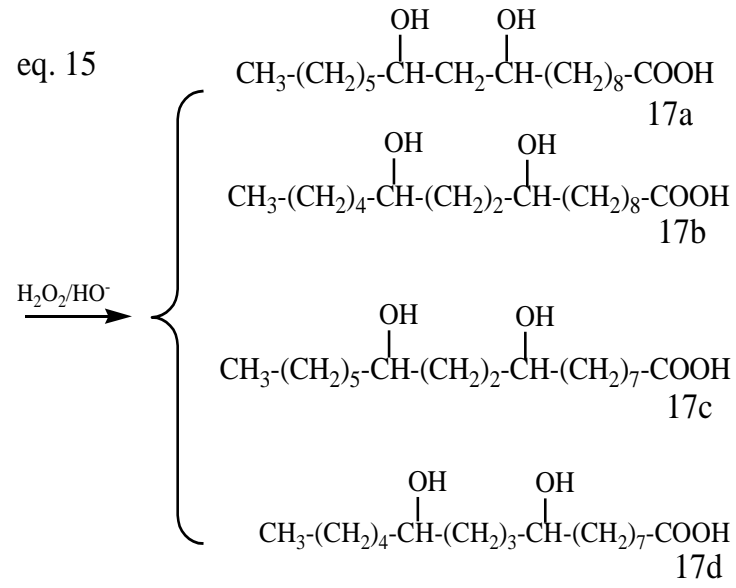

NMR Carbon spectrum of this mixture of acids indicates the presence of five signals at 71.90, 71.99, 72.14, 72.40, and $72.49 \mathrm{ppm}$ for $\mathrm{CH}-\mathrm{OH}$ and three signals for the carbonyl group: 178.82, 178.88, and $178.99 \mathrm{ppm}$. Therefore, this confirms the training of several isomers. To analyze these hydroxyacids by HPLC coupled with mass spectrometry, we transform the acids in hydroxyesters (eq. 16). 


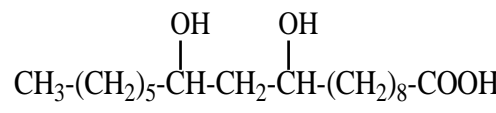<smiles>CCCCCC(O)CC(O)CCC(=O)O</smiles><smiles>CCCCCC(O)CC(O)CCC(=O)O</smiles><smiles>CCCCCC(O)CCC(O)CCC(=O)O</smiles>

eq. 16<smiles>CCCCCC(O)CC(O)CC(=O)OC</smiles><smiles>CCCCCCC(O)CCC(O)CC(=O)OC</smiles>
$18 \mathrm{~b}$

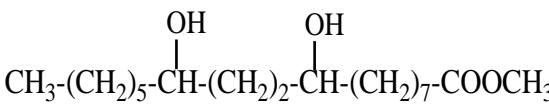
$18 \mathrm{c}$<smiles>CCCCCCC(O)CCC(O)CC(=O)OC</smiles>

Subsequently, we tried to establish the possible fragmentation based on this literature. Also, we indicate the different possibilities in the diagram below.
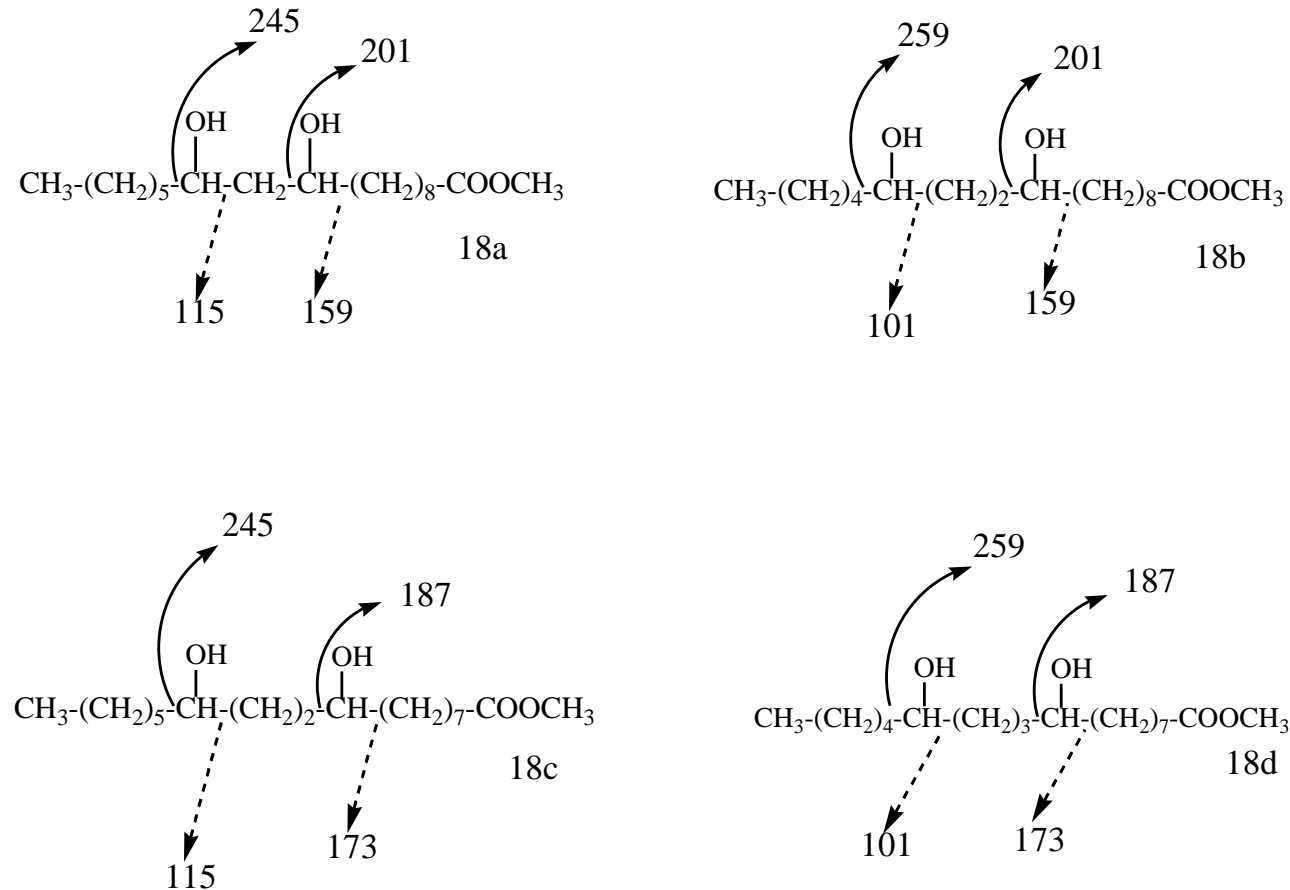

The study of mass spectra in Electron impact showed the presence of four Positional isomers: 18a, 18b, 18c, and 18d with the characteristic fragments of masses 245 and 259 amu. In this study, we concluded that under the operating conditions used, the hydroboration reactions by BMS on the two double bonds are not regioselective. 


\section{Conclusion}

The hydroboration reactions of unsaturated methyl esters use various boranes (BMS BBN). Firstly, it shows that the stoichiometry of the reactants is the determining factor and a ratio of 1/3 (BMS / EMAG) gives the best results. While these reactions are perfectly regioselective in the case of undecenoate methyl, these results show that using intermediate organoboranes allows for easy functionalizing of the chain methyl esters of unsaturated fatty acids.

\section{Experimental Method}

Synthesis of Tri (10-methoxycarbonyl decyl) Borane 1

A undec-10-enoic acid methyl ester $(0.75 \mathrm{~g}, 3.79 \mathrm{mmol})$ in $3 \mathrm{ml}$ of THF was added drop wise to BMS $(0.70 \mathrm{ml}, 1.40 \mathrm{mmol})$ in solution in THF (2 M). The mixture is stirred for three hours at room temperature. The concentration of solvent under reduced pressure leads to the obtaining of 0.68 $\mathrm{g}$ of a viscous liquid which is product $1(89 \%)$.

IR: $\mathrm{n}(\mathrm{C}=\mathrm{O})=1741 \mathrm{~cm}^{-1}$.

RMN ${ }^{1} \mathbf{H}$ (CDCl3) (300.13 MHz): $\square(\mathrm{ppm})=0.79\left(\mathrm{t},{ }^{3} \mathrm{JHH}=6.9 \mathrm{~Hz}, 2 \mathrm{H}\right.$, $\left.\mathrm{CH}_{2}-\mathrm{BH}_{2}\right) ; 1.21$ (s.1,

$\left.14 \mathrm{H},\left(\mathrm{CH}_{2}\right)_{7}\right) ; 1.56\left(\mathrm{~m}, 2 \mathrm{H}, \mathrm{CH}_{2}-\mathrm{CH}_{2}-\mathrm{CO}\right) ; 2.25\left(\mathrm{t},{ }^{3} \mathrm{JHH}=7.2 \mathrm{~Hz}, 2 \mathrm{H}, \mathrm{CH}_{2}-\right.$ $\mathrm{CO}) ; 3.61(\mathrm{~s}, 3 \mathrm{H}$,

$\left.\left.\mathrm{OCH}_{3}\right) . \mathbf{R M N}^{13} \mathbf{C}\left(\mathbf{C D C l}_{3}\right) \mathbf{( 7 5 . 4 8} \mathbf{M H z}\right): \square(\mathrm{ppm})=24.93,29.14,29.25$, 29.36, 29.46, 29.55, $29.64\left(\left(\mathrm{CH}_{2}\right) 9\right) ; 34.06\left(\mathrm{CH}_{2}-\mathrm{CO}\right) ; 51.86\left(\mathrm{OCH}_{3}\right) ; 174.22$ (CO).

Synthesis of Bis (10-méthoxycarbonyldécyl) Thexylborane 2:

A solution of methyl undec-10-enoate $(0.79 \mathrm{~g}, 3.99 \mathrm{mmol})$ in $3 \mathrm{ml}$ of THF, was added drop wise to the thexylborane $(0.20 \mathrm{~g}, 2.04 \mathrm{mmol})$. It was dissolved in THF to $-5^{\circ} \mathrm{C}$. The reaction mixture is stirred for three hours at $20^{\circ} \mathrm{C}$. In addition, $1.67 \mathrm{~g}$ of a viscous liquid is the product $2(84 \%)$.

IR: $\mathrm{n}(\mathrm{C}=\mathrm{O})=1741 \mathrm{~cm}^{-1}$.

RMN ${ }^{1} \mathbf{H}(\mathbf{C D C l})$ (300.13 MHz): $\square(\mathrm{ppm})=0.65\left(\mathrm{~d},{ }^{3} \mathrm{JHH}=6.9 \mathrm{~Hz}, 6 \mathrm{H}\right.$, $\left.\mathrm{CH}\left(\mathrm{CH}_{3}\right)_{2}\right) ; 0.68$ (s,

$\left.6 \mathrm{H}, \mathrm{C}\left(\mathrm{CH}_{3}\right)_{2}\right) ; 1.11$ (m, 4H, B-CH 2$) ; 1.21$ (s.1, 28H, (CH2)7); $1.55(\mathrm{~m}, 4 \mathrm{H}$, $\mathrm{CH} 2-\mathrm{CH} 2-\mathrm{CO})$;

1.83 (sept, $\left.{ }^{3} \mathrm{JHH}=6.8 \mathrm{~Hz}, 1 \mathrm{H}, \mathrm{CH}\right) ; 2.23\left(\mathrm{t},{ }^{3} \mathrm{JHH}=7.4 \mathrm{~Hz}, 4 \mathrm{H}, \mathrm{CH}_{2}-\mathrm{CO}\right)$; $3.60\left(\mathrm{~s}, 6 \mathrm{H}, \mathrm{OCH}_{3}\right)$.

$\mathbf{R M N}^{13} \mathbf{C}\left(\mathbf{C D C l}_{3}\right)$ (75.48 $\left.\left.\mathbf{M H z}\right): \square(\mathrm{ppm})=18.46 \mathrm{CH}\left(\mathrm{CH}_{3}\right)\right) ; 19.57$ $\left.\mathrm{C}\left(\mathrm{CH}_{3}\right)_{2}\right) ; 24.59,24.96$,

29.17, 29.27, 29.49 et $\left.29.56\left(\mathrm{CH}_{2}-\left(\mathrm{CH}_{2}\right)_{7}-\mathrm{CH}_{2}\right) ; 33.28 \mathrm{CH}\left(\mathrm{CH}_{3}\right)_{2}\right) ; 33.47$ $\left.\mathrm{C}\left(\mathrm{CH}_{3}\right)_{2}\right) ; 34.09$

$\left(\mathrm{CH}_{2}-\mathrm{CO}\right) ; 51.37\left(\mathrm{OCH}_{3}\right) ; 174.26(\mathrm{CO})$. 
Synthesis of Product Number 3

Undec-10-enoic acid methyl ester $(0.75 \mathrm{~g}, 3.79 \mathrm{mmol})$ in $3 \mathrm{ml}$ of THF was added drop wise to BBN $(8.30 \mathrm{ml}, 4.17 \mathrm{mmol})$ in solution in THF (0.5 $\mathrm{M})$. The mixture is stirred for three hours at room temperature and then one hour at $50^{\circ} \mathrm{C}$. The concentration of the solvent under reduced pressure leads to a viscous liquid. Therefore, the analysis by proton NMR shows the formation of $83 \%$ of the product 3 .

IR: $\mathrm{n}(\mathrm{C}=\mathrm{O})=1740 \mathrm{~cm}^{-1}$.

$\mathbf{R M N}{ }^{1} \mathbf{H}(\mathbf{C D C l})$ (300.13 MHz): $\square(\mathrm{ppm})=1.21\left(\mathrm{~s} .1,16 \mathrm{H},\left(\mathrm{CH}_{2}\right)_{8}\right) ; 1.57(\mathrm{~m}$, $2 \mathrm{H}, \mathrm{CH}_{2}-\mathrm{CH}_{2}-$

$\mathrm{CO}) ; 1.62-1.78\left(\mathrm{~m}, 14 \mathrm{H}, \mathrm{CH}, \mathrm{CH}_{2}(\mathrm{BBN})\right) ; 2.22\left(\mathrm{t},{ }^{3} \mathrm{JHH}=7.2 \mathrm{~Hz}, 2 \mathrm{H}, \mathrm{CH}_{2^{-}}\right.$ $\mathrm{CO}) ; 3.49$ (s, $3 \mathrm{H}$,

$\mathrm{OCH} 3)$.

$\mathbf{R M N}^{13} \mathbf{C}\left(\mathbf{C D C l}_{3}\right)$ (75.48 MHz): $\square(\mathrm{ppm})=23.21,24.41,24.92,29.13,29.23$, 29.45, 29.55,

29.58, 32.90, $33.10\left(\left(\mathrm{CH}_{2}\right)_{9}\right.$ et $\left.\mathrm{CH}_{2}(\mathrm{BBN})\right) ; 34.02\left(\mathrm{CH}_{2}-\mathrm{CO}\right) ; 51.26\left(\mathrm{OCH}_{3}\right)$; $174.12(\mathrm{CO})$.

\section{Synthesis of 11-Hydroxyundécanoïque 4}

To a solution of organoborane $\left(\mathrm{B}\left(\left(\mathrm{CH}_{2}\right)_{10}-\mathrm{COOMe}\right)_{3}\right)(0.76 \mathrm{~g}, 1.26$ $\mathrm{mmol})$ in $3.5 \mathrm{ml}$ of acetone, $1.5 \mathrm{ml}$ of $\mathrm{HCl}(5 \%)$ were added drop wise. The residue was then dissolved in $3.5 \mathrm{ml}$ of THF. The resulting solution is alkalinized by $3.75 \mathrm{ml} \mathrm{NaOH}$ (40\%), and was then treated slowly with $5.7 \mathrm{ml}$ of a solution of $30 \% \mathrm{H}_{2} \mathrm{O}_{2}$.

The mixture is then refluxed during three hours. After cooling, the reaction mixture is acidified with a solution of $35 \% \mathrm{HCl}$. The organic phase was collected and the aqueous phase is extracted with chloroform. The phases organic are combined and dried over sodium sulfate. Evaporation of the solvents leads to obtaining of a white solid. Crystallization from ether at low temperature $\left(-30^{\circ} \mathrm{C}\right)$ leads to $0.71 \mathrm{~g}$ of a white solid that was identified 4 (93\%).

FP: $61-68^{\circ} \mathrm{C}$

IR: $\mathrm{n}(\mathrm{C}=\mathrm{O})=1693 \mathrm{~cm}^{-1} ; \mathrm{n}(\mathrm{O}-\mathrm{H})=3365 \mathrm{~cm}^{-1}$.

RMN 1H (CDCl 3$)$ (300.13 MHz): $\square(\mathrm{ppm})=1.24$ (s.1, 12H, $\left.\left(\mathrm{CH}_{2}\right)_{6}\right) ; 1.52$ (m, $4 \mathrm{H}, \mathrm{CH}_{2}-\mathrm{CH}_{2-}$

$\mathrm{CO}$ et $\left.\mathrm{CH}_{2}-\mathrm{CH}_{2}-\mathrm{OH}\right) ; 2.28\left(\mathrm{t},{ }^{3} \mathrm{JHH}=7.4 \mathrm{~Hz}, 2 \mathrm{H}, \mathrm{CH}_{2}-\mathrm{CO}\right) ; 3.58(\mathrm{t}, 3 \mathrm{JHH}=$ $6.6 \mathrm{~Hz}, 2 \mathrm{H}$,

$\left.\left.\mathrm{CH}_{2}-\mathrm{OH}\right) . \mathbf{R M N}{ }^{13} \mathbf{C}\left(\mathbf{C D C l}_{3}\right) \mathbf{( 7 5 . 4 8} \mathbf{M H z}\right): \square(\mathrm{ppm})=24.69,25.67,29.15$, 29.27, 29.31, 29.43, 29.54

$\left.\left(\mathrm{CH}_{2}\right)_{7}\right) ; 32.69\left(\mathrm{CH}_{2}-\mathrm{CH}_{2}-\mathrm{CO}\right) ; 33.98\left(\mathrm{CH}_{2}-\mathrm{CO}\right) ; 63.03\left(\mathrm{CH}_{2}-\mathrm{OH}\right) ; 178.94$ (CO). 
Masse: (IE, $70 \mathrm{eV}) \mathbf{m} / \mathbf{z}=[\mathrm{M}+1]^{+}=203(4 \%) ;\left[\mathrm{M}-\mathrm{H}_{2} \mathrm{O}\right]^{+}=184(11 \%)$; $\left[\mathrm{CH}_{3}-\mathrm{COOH}\right]^{+}=$ $60(29 \%)$.

\section{Synthesis of Undecan-1, 11-diol 5}

Undec-10-enoic acid methyl ester $(0.50 \mathrm{~g}, 2.53 \mathrm{mmol})$ in $3 \mathrm{ml}$ of THF was added drop wise to BMS $(3.79 \mathrm{ml}, 7.58 \mathrm{mmol})$ dissolved in THF (2 M). The mixture is stirred for three hours at room temperature. After the oxidation of hydrogen peroxide in an alkaline medium by following the same high oxidation protocol, a White solid was obtained. The analysis thereof by proton NMR shows the formation of $89 \%$ of products 5 .

IR: $\mathrm{n}(\mathrm{O}-\mathrm{H})=3300 \mathrm{~cm}^{-1}$.

$\left.\mathbf{R M N}^{1} \mathbf{H}\left(\mathbf{C D C}^{\mathbf{l} 3}\right) \mathbf{( 3 0 0 . 1 3} \mathbf{M H z}\right): \square(\mathrm{ppm})=1.22\left(\mathrm{~s} .1,14 \mathrm{H},\left(\mathrm{CH}_{2}\right)_{7}\right) ; 1.49(\mathrm{~m}$, $4 \mathrm{H}, \mathrm{CH}_{2}-\mathrm{CH}_{2}-$

$\mathrm{OH}) ; 3.56\left(\mathrm{t},{ }^{3} \mathrm{JHH}=6.5 \mathrm{~Hz}, 4 \mathrm{H}, \mathrm{CH}_{2}-\mathrm{OH}\right)$.

Synthesis of 11-methyl Hydroxyundécanoate 6

To a solution of 11-hydroxyundecanoïque $(2.00 \mathrm{~g}, 9.90 \mathrm{mmol})$ in $6 \mathrm{ml}$ of methanol, a few drops of sulfuric acid were added. The mixture is heated at $60{ }^{\circ} \mathrm{C}$ for one hour, and then refluxed for an additional hour. It is then neutralized with a diluted $\mathrm{Na}_{2} \mathrm{CO}_{3}$ solution $(1.0 \mathrm{~mL}, 10 \%)$. The organic phase is extracted twice with $3 \mathrm{ml}$ pentane and then dried over $\mathrm{Na}_{2} \mathrm{SO}_{4}$. After evaporation, we obtain $1.08 \mathrm{~g}$ of 6 as a clear liquid $(51 \%)$.

IR: $\mathrm{n}(\mathrm{C}=\mathrm{O})=1740 \mathrm{~cm}^{-1} ; \mathrm{n}(\mathrm{O}-\mathrm{H})=3340 \mathrm{~cm}^{-1}$.

$\mathbf{R M N}^{1} \mathbf{H}\left(\mathbf{C D C l}_{3}\right)(\mathbf{3 0 0 . 1 3} \mathrm{MHz}): \mathrm{d}(\mathrm{ppm})=1.25\left(\mathrm{~s} .1,12 \mathrm{H},\left(\mathrm{CH}_{2}\right)_{6}\right) ; 1.62(\mathrm{~m}$, $4 \mathrm{H}, \mathrm{CH}_{2}-\mathrm{CH}_{2}-$

$\mathrm{CO}$ et $\left.\mathrm{CH}_{2}-\mathrm{CH}_{2}-\mathrm{OH}\right) ; 2.29\left(\mathrm{t},{ }^{3} \mathrm{JHH}=7.4 \mathrm{~Hz}, 2 \mathrm{H}, \mathrm{CH}_{2}-\mathrm{CO}\right) ; 3.62\left(\mathrm{t},{ }^{3} \mathrm{JHH}=\right.$ $6.6 \mathrm{~Hz}, 2 \mathrm{H}$,

$\left.\mathrm{CH}_{2}-\mathrm{OH}\right) ; 3.66$ (s, 3H, $\left.\mathrm{OCH}_{3}\right)$.

RMN ${ }^{13}$ C (C6D6) (75.48 MHz): $\square(\mathrm{ppm})=24.80,25.89,29.03,29.23,29.41$, $29.50,29.59$

$\left.\left(\mathrm{CH}_{2}\right)_{7}\right) ; 32.81\left(\mathrm{CH}_{2}-\mathrm{CH}_{2}-\mathrm{OH}\right), 33.70\left(\mathrm{CH}_{2}-\mathrm{CO}\right) ; 50.64\left(\mathrm{OCH}_{3}\right) ; 61.98\left(\mathrm{CH}_{2}-\right.$ $\mathrm{OH}) ; 173.23$

(CO).

Masse: $($ IE, $70 \mathrm{eV}) \mathbf{m} / \mathbf{z}=[\mathrm{M}+1]^{+}=217(1 \%) ;[(\mathrm{M}+1)-\mathrm{OMe}]^{+}=186$ (9\%); $\left[\mathrm{M}-\mathrm{CH}_{2-}\right.$

$\mathrm{COOMe})]^{+}=143(11 \%) ;\left[\mathrm{CH}_{3} \mathrm{COOCH}_{3}\right]^{+}=74(100 \%)$.

\section{Synthesis of Undecanol 7}

Methyl undecanoate $(0.75 \mathrm{~g}, 3.59 \mathrm{mmol})$ in $3 \mathrm{ml}$ of $\mathrm{THF}$ was added drop wise to the BMS $(2.05 \mathrm{ml}, 4.10 \mathrm{mmol})$ in solution in THF $(2 \mathrm{M})$. The mixture is stirred for three hours at room temperature. After the oxidation of hydrogen peroxide in an alkaline medium by following the same high 
oxidation protocol analysis, Proton NMR of the reaction mixture showed the formation of $42 \%$ of the product 7 .

RMN ${ }^{1} \mathbf{H}\left(\mathbf{C D C l}_{3}\right)(\mathbf{3 0 0 . 1 3} \mathbf{M H z}): \square(\mathrm{ppm})=0.83\left(\mathrm{t},{ }^{3} \mathrm{JHH}=6.1 \mathrm{~Hz}, 3 \mathrm{H}\right.$, $\left.\mathrm{CH}_{3}\right) ; 1.21$ (s.1, 18H,

$\left.\left(\mathrm{CH}_{2}\right)_{9}\right) ; 1.53\left(\mathrm{~m}, 2 \mathrm{H}, \mathrm{CH}_{2}-\mathrm{CH}_{2}-\mathrm{OH}\right) ; 3.59$ (t, $\left.{ }^{3} \mathrm{JHH}=6.6 \mathrm{~Hz}, 2 \mathrm{H}, \mathrm{CH}_{2}-\mathrm{OH}\right)$.

\section{Synthesis of 8}

BMS $(2.50 \mathrm{ml}, 5.00 \mathrm{mmol})$ in solution in THF $(2 \mathrm{M})$ was added to a solution chloride undec-10 enoyl $(1.00 \mathrm{~g}, 4.59 \mathrm{mmol})$ in $4 \mathrm{ml}$ of THF. The mixture is then stirred for three hours at room temperature. Evaporation of solvent results in the formation of $1.01 \mathrm{~g}$ of the product 8 as a viscous liquid (94\%).

IR: $\mathrm{n}(\mathrm{C}=\mathrm{O})=1712 \mathrm{~cm}^{-1}$.

RMN ${ }^{1} \mathbf{H}(\mathbf{C D C l})_{3}$ (300.13 MHz): $\square(\mathrm{ppm})=0.85\left(\mathrm{~m}, 2 \mathrm{H},\left(\mathrm{CH}_{2}-\mathrm{BH}_{2}\right) ; 1.21\right.$ (s.1, 14H,

$\left(\left(\mathrm{CH}_{2}\right)_{7}\right) ; 1.63\left(\mathrm{~m}, 2 \mathrm{H}, \mathrm{CH}_{2}-\mathrm{CH}_{2}-\mathrm{CO}\right) ; 2.82\left(\mathrm{t},{ }^{3} \mathrm{JHH}=7.2 \mathrm{~Hz}, 2 \mathrm{H}, \mathrm{CH}_{2}-\mathrm{CO}\right)$. $\mathbf{R M N}^{13} \mathbf{C}\left(\mathbf{C D C l}_{3}\right)$ (75.48 MHz): $\square(\mathrm{ppm})=22.68\left(\mathrm{CH}_{2}-\mathrm{B}\right) ; 24.51,25.07$, 28.44, 29.09, 29.37,

29.51, $29.56\left(\left(\mathrm{CH}_{2}\right)_{7}\right) ; 33.00\left(\mathrm{CH}_{2}-\mathrm{CH}_{2}-\mathrm{CO}\right) ; 47.11\left(\mathrm{CH}_{2}-\mathrm{CO}\right) ; 173.71(\mathrm{CO})$.

\section{Synthesis of 9}

BBN (10.09 mL, $5.05 \mathrm{mmol})$ in solution in THF $(0.5 \mathrm{M})$ was added to a chloride solution of undec-10-enoyl $(1.00 \mathrm{~g}, 4.59 \mathrm{mmol})$ in $6 \mathrm{ml}$ of THF. The mixture is then stirred for five hours at $50^{\circ} \mathrm{C}$. Evaporation of the solvent leads to the production of $1.10 \mathrm{~g}$ of a viscous liquid. The analysis of the latter NMR proton shows the formation of $83 \%$ of the product 9 .

IR: $\mathrm{n}(\mathrm{C}=\mathrm{O})=1714 \mathrm{~cm}^{-1}$.

RMN ${ }^{1} \mathrm{H}\left(\mathbf{C D C l}_{3}\right)$ (300.13 MHz): $\square(\mathrm{ppm})=1.23$ (s.1, 16H, $\left(\mathrm{CH}_{2}-\left(\mathrm{CH}_{2}\right)_{7}\right)$; $1.64\left(\mathrm{~m}, 2 \mathrm{H}, \mathrm{CH}_{2}-\right.$

$\left.\mathrm{CH}_{2}-\mathrm{CO}\right) ; 1.62-1.80\left(\mathrm{~m}, 14 \mathrm{H}, \mathrm{CH}, \mathrm{CH}_{2}(\mathrm{BBN})\right) ; 2.83\left(\mathrm{t},{ }^{3} \mathrm{JHH}=7.2 \mathrm{~Hz}, 2 \mathrm{H}\right.$, $\mathrm{CH}_{2}-\mathrm{CO}$ ).

\section{Synthesis of N-10-enamide phénylundéc 10:}

A mixture of methyl undec-10-enoate $(2.67 \mathrm{~g}, 13.48 \mathrm{mmol})$ and aniline ( $1.53 \mathrm{~g}, 16.45 \mathrm{mmol}$ ) was heated in Carius tube for 24 hours at $200^{\circ} \mathrm{C}$. The solution was treated with pentane. After filtering the solution, washing with pentane $(5 \times 4 \mathrm{ml})$ leads to $2.42 \mathrm{~g}$ of a white powder $10(72 \%)$.

FP: $102{ }^{\circ} \mathrm{C}$.

IR (nujol): $\mathrm{n}(\mathrm{C}=\mathrm{C})=1640 \mathrm{~cm}^{-1} ; \mathrm{n}(\mathrm{C}=\mathrm{O})=1663 \mathrm{~cm}^{-1} ; \mathrm{n}(\mathrm{N}-\mathrm{H})=3304 \mathrm{~cm}^{-1}$. $\mathbf{R M N}^{1} \mathbf{H}\left(\mathbf{C D C l}_{3}\right)$ (300.13 MHz): $\square(\mathrm{ppm})=1.24\left(\mathrm{~s} .1,10 \mathrm{H},\left(\mathrm{CH}_{2}\right)_{5}\right) ; 1.65(\mathrm{~m}$, $2 \mathrm{H}, \mathrm{CH}_{2}-\mathrm{CH}_{2}-$ 
$\mathrm{CO}) ; 1.97\left(\mathrm{~m}, 2 \mathrm{H}, \mathrm{CH}_{2}-\mathrm{CH}=\mathrm{CH}_{2}\right) ; 2.28\left(\mathrm{t},{ }^{3} \mathrm{JHH}=7.0 \mathrm{~Hz}, 2 \mathrm{H}, \mathrm{CH}_{2}-\mathrm{CO}\right) ; 4.90$ $(\mathrm{m}, 2 \mathrm{H}$,

$\left.\mathrm{CH}_{2}=\mathrm{CH}\right) ; 5.74\left(\mathrm{~m}, 1 \mathrm{H}, \mathrm{CH}=\mathrm{CH}_{2}\right) ; 7.01-7.22\left(\mathrm{~m}, 5 \mathrm{H}, \mathrm{C}_{6} \mathrm{H}_{5}\right)$.

$\left.\mathbf{R M N}^{13} \mathbf{C}\left(\mathbf{C D C l}_{3}\right) \mathbf{( 7 5 . 4 8} \mathbf{M H z}\right): \square(\mathrm{ppm})=26.02,29.24,29.44,29.60,29.74$, $\left.\left(\mathrm{CH}_{2}\right)_{5}\right) ; 34.12$

$\left.\mathrm{CH}_{2}-\mathrm{CH}=\mathrm{CH}_{2}\right) ; 38.15\left(\mathrm{CH}_{2}-\mathrm{CO}\right) ; 114.51\left(\mathrm{CH}_{2}=\mathrm{CH}\right) ; 120.21(\mathrm{Co}), 124.53$ (Cp), $129.35(\mathrm{Cm})$;

138.46 (Cipso); $139.52\left(\mathrm{CH}_{2}=\mathrm{CH}\right) ; 171.81(\mathrm{CO})$.

Masse $(\mathrm{IE}, 70 \mathrm{eV}) \mathbf{m} / \mathbf{z}=[\mathrm{M}]^{+.}=259(6 \%) ;\left[\left(\mathrm{CH}_{2}=\mathrm{CH}-\left(\mathrm{CH}_{2}\right)_{8}-\mathrm{CO}\right)\right]^{+}=167$ $(10 \%) ;\left[\mathrm{PhNH}_{2}\right]^{+}$ $=93(100 \%)$.

\section{Synthesis of 11}

Using the same protocol of hydroboration, BMS $(0.35 \mathrm{ml}, 0.7 \mathrm{mmol})$ in solution in THF (2 M) was added to a solution of N-phenylundec-10enamide $(1.00 \mathrm{~g}, 4.95 \mathrm{mmol})$ in $2 \mathrm{ml}$ of THF. The mixture is then stirred for three hours at room temperature. After evaporating the solvent, washing with pentane $(2 \times 3 \mathrm{~mL})$ leads to $0.50 \mathrm{~g}$ of a yellow solid compounds $11(98 \%)$.

IR: $\mathrm{n}(\mathrm{C}=\mathrm{O})=1656 \mathrm{~cm}^{-1} ; \mathrm{n}(\mathrm{N}-\mathrm{H})=3304 \mathrm{~cm}^{-1}$.

$\mathrm{RMN}^{11} \mathrm{~B}\left(\mathrm{CDCl}_{3}\right)$ (96.29 MHz): $\square(\mathrm{ppm})=6.80$.

$\mathbf{R M N}^{1} \mathbf{H}\left(\mathbf{C D C l}_{3}\right)(\mathbf{3 0 0 . 1 3} \mathbf{M H z}): \square(\mathrm{ppm})=0.81\left(\mathrm{t},{ }^{3} \mathrm{JHH}=6.6 \mathrm{~Hz}, 2 \mathrm{H}\right.$, $\mathrm{CH}_{2}-\mathrm{BH}_{2}$ ); 1.20 (s.l,

$\left.14 \mathrm{H},\left(\mathrm{CH}_{2}\right)_{7}\right) ; 1.65\left(\mathrm{~m}, 2 \mathrm{H}, \mathrm{CH}_{2}-\mathrm{CH}_{2}-\mathrm{CO}\right) ; 2.28\left(\mathrm{t},{ }^{3} \mathrm{JHH}=7.5 \mathrm{~Hz}, 2 \mathrm{H}, \mathrm{CH}_{2}-\right.$ $\mathrm{CO}) ; 7.00-7.46$

$\left(\mathrm{m}, 5 \mathrm{H}, \mathrm{C}_{6} \mathrm{H}_{5}\right)$.

$\mathbf{R M N}^{13} \mathbf{C}\left(\mathbf{C D C l}_{3}\right)(\mathbf{7 5 . 4 8} \mathbf{M H z}): \square(\mathrm{ppm})=22.70\left(\mathrm{CH}_{2}-\mathrm{B}\right) ; 25.68,29.31$, 29.33, 29.41, 29.51

$\left(\left(\mathrm{CH}_{2}\right)_{7}\right) ; 31.91\left(\mathrm{CH}_{2}-\mathrm{CH}_{2}-\mathrm{CO}\right) ; 37.85\left(\mathrm{CH}_{2}-\mathrm{CO}\right) ; 119.86(\mathrm{Co}) ; 124.17(\mathrm{Cp})$; $128.97(\mathrm{Cm})$;

138.03 (Cipso); 171.65 (CO).

\section{Synthesis of 12}

A solution of N-phénylundéc-10-enamide $(0.25 \mathrm{~g}, 0.97 \mathrm{mmol})$ in $2 \mathrm{ml}$ of THF was added drop wise to the thexylborane $(0.05 \mathrm{~g}, 0.50 \mathrm{mmol})$ in THF solution at $-5^{\circ} \mathrm{C}$. The reaction mixture is stirred for three hours at room temperature. Therefore, we obtained $0.45 \mathrm{~g}$ of a viscous white solid $12(75 \%)$. IR: $\mathrm{n}(\mathrm{C}=\mathrm{O})=1660 \mathrm{~cm}^{-1} ; \mathrm{n}(\mathrm{N}-\mathrm{H})=3314 \mathrm{~cm}^{-1}$.

$\mathbf{R M N}^{1} \mathbf{H}\left(\mathbf{C D C l}_{3}\right)(\mathbf{3 0 0 . 1 3} \mathbf{M H z}): \square(\mathrm{ppm})=0.70$ (s.1, 12H, $\left.\mathrm{CH}_{3}\right)$; (s.1, 32H, $\left.\left(\mathrm{CH}_{2}-\mathrm{CH}_{2}\right)_{7}\right)$;

$1.63\left(\mathrm{~m}, 4 \mathrm{H}, \mathrm{CH}_{2}-\mathrm{CH}_{2}-\mathrm{CO}\right) ; 1.83(\mathrm{~m}, 1 \mathrm{H}, \mathrm{CH}) ; 2.28\left(\mathrm{t},{ }^{3} \mathrm{JHH}=7.4 \mathrm{~Hz}, 4 \mathrm{H}\right.$, $\left.\mathrm{CH}_{2}-\mathrm{CO}\right) ; 7.04-$

$7.48\left(\mathrm{~m}, 10 \mathrm{H}, \mathrm{C}_{6} \mathrm{H}_{5}\right)$. 
$\mathbf{R M N}^{13} \mathbf{C}\left(\mathbf{C D C l}_{3}\right)$ (75.48 $\left.\left.\mathbf{M H z}\right): \square(\mathrm{ppm})=18.58 \mathrm{CH}\left(\mathrm{CH}_{3}\right)_{2}\right) ; 19.02$ $\left.\mathrm{C}\left(\mathrm{CH}_{3}\right)_{2}\right) ; 21.32,22.29$,

23.52, 24.75, 28.35, 28.44, 28.56, 31.22 et $31.57\left(\mathrm{CH}_{2}-\left(\mathrm{CH}_{2}\right)_{7}-\mathrm{CH}_{2}\right) ; 32.28$ $\left.\mathrm{CH}\left(\mathrm{CH}_{3}\right)_{2}\right) ; 32.38$

$\left.\mathrm{C}\left(\mathrm{CH}_{3}\right)_{2}\right) ; 36.71\left(\mathrm{CH}_{2}-\mathrm{CO}\right) ; 118.94(\mathrm{Co}) ; 123.07(\mathrm{Cp}) ; 127.84(\mathrm{Cm}) ; 137.14$ (Cipso); 170.98

(CO).

\section{Synthesis of $13(\mathbf{a}, \mathbf{b})$}

A solution of methyl oleate $(0.75 \mathrm{~g}, 2.53 \mathrm{mmol})$ in $3 \mathrm{ml}$ of THF was added drop wise to BMS $(1.30 \mathrm{ml}, 2.60 \mathrm{mmol})$ in solution in THF $(2 \mathrm{M})$. The mixture is stirred for four hours at room temperature. The concentration of solvent under reduced pressure leads to the obtaining of a $0.70 \mathrm{~g}$ of a viscous liquid $(89 \%)$.

IR: $\mathrm{n}(\mathrm{C}=\mathrm{O})=1740 \mathrm{~cm}^{-1}$.

$\mathbf{R M N}^{1} \mathbf{H}\left(\mathbf{C D C l}_{3}\right)(\mathbf{3 0 0 . 1 3} \mathbf{M H z}): \square(\mathrm{ppm})=0.83\left(\mathrm{t},{ }^{3} \mathrm{JHH}=6.0 \mathrm{~Hz}, 3 \mathrm{H}\right.$, $\left.\mathrm{CH}_{3}\right) ; 1.20$ (s.1, 26H,

$\left(\mathrm{CH}_{2}\right)_{7}-\mathrm{CH}-\left(\mathrm{CH}_{2}\right)_{6}$ et $\left.\left.\left(\mathrm{CH}_{2}\right)_{8}-\mathrm{CH}-\left(\mathrm{CH}_{2}\right)_{5}\right)\right) ; 1.56\left(\mathrm{~m}, 2 \mathrm{H}, \mathrm{CH}_{2}-\mathrm{CH}_{2}-\mathrm{CO}\right) ; 2.24$

$\left(\mathrm{t},{ }^{3} \mathrm{JHH}=7.4\right.$

$\left.\mathrm{Hz},{ }^{2} \mathrm{H}, \mathrm{CH}_{2}-\mathrm{CO}\right) ; 3.60$ (s, $\left.3 \mathrm{H}, \mathrm{OCH}_{3}\right)$.

$\left.\mathbf{R M N}^{13} \mathbf{C}\left(\mathbf{C D C l}_{3}\right) \mathbf{( 7 5 . 4 8} \mathbf{~ M H z}\right): \square(\mathrm{ppm})=14.10\left(\mathrm{CH}_{3}\right) ; 22.70,24.95,25.63$, 29.40, 29.69,

$30.23,30.50,31.39,31.94\left(\mathrm{CH}_{2) 7}-\mathrm{CH}-\left(\mathrm{CH}_{2}\right)_{6}\right.$ et $\left.\left.\left(\mathrm{CH}_{2}\right)_{8}-\mathrm{CH}-\left(\mathrm{CH}_{2}\right)_{5}\right)\right) ; 34.06$ $\left(\mathrm{CH}_{2}-\mathrm{CO}\right) ; 51.37$

$\left(\mathrm{OCH}_{3}\right) ; 174.26(\mathrm{CO})$.

Synthesis of 9-hydroxyoctadecanoic acid and 10-hydroxyoctadecanoic acid and $14 \mathrm{a}$ $14 \mathrm{~b}$

A solution of organoboranes $(0.70 \mathrm{~g}, 2.27 \mathrm{mmol})$ obtained from the hydroboration of methyl oleate in $4 \mathrm{ml}$ of acetone are added drop wise to $1 \mathrm{ml}$ of $\mathrm{HCl}(5 \%)$. When the hydrogen evolving has ceased, the solvent was concentrated in vacuum. Also, the residue was then dissolved in $5 \mathrm{ml}$ THF. The resulting solution is alkalinized by $6.74 \mathrm{ml} \mathrm{NaOH} \mathrm{(40 \% ).} \mathrm{Then,} \mathrm{it} \mathrm{was}$ treated slowly with $10.25 \mathrm{ml}$ with a solution of $30 \% \mathrm{H}_{2} \mathrm{O}_{2}$. The mixture is then refluxed for three hours. After cooling, the reaction mixture is acidified with a solution of $35 \% \mathrm{HCl}$. The organic phase was collected and the aqueous phase is extracted with chloroform. The phases organic are combined and dried over sodium sulfate. After Evaporation, we obtained $0.54 \mathrm{~g}$ of a white solid identified at $14 \mathrm{a}$ and $14 \mathrm{~b}$.

IR: $\mathrm{n}(\mathrm{C}=\mathrm{O})=1660 \mathrm{~cm}^{-1} ; \mathrm{n}(\mathrm{N}-\mathrm{H})=3314 \mathrm{~cm}^{-1}$. 
RMN ${ }^{1} \mathbf{H}\left(\mathbf{C D C l}_{3}\right)(\mathbf{3 0 0 . 1 3} \mathbf{M H z}): \square(\mathrm{ppm})=0.70$ (s.1, 12H, $\left.\mathrm{CH}_{3}\right)$; (s.1, 32H, $\left.\left(\mathrm{CH}_{2}-\mathrm{CH}_{2}\right)_{7}\right)$;

$1.63\left(\mathrm{~m}, 4 \mathrm{H}, \mathrm{CH}_{2}-\mathrm{CH}_{2}-\mathrm{CO}\right) ; 1.83(\mathrm{~m}, 1 \mathrm{H}, \mathrm{CH}) ; 2.28\left(\mathrm{t},{ }^{3} \mathrm{JHH}=7.4 \mathrm{~Hz}, 4 \mathrm{H}\right.$, $\left.\mathrm{CH}_{2}-\mathrm{CO}\right) ; 7.04-$

$7.48\left(\mathrm{~m}, 10 \mathrm{H}, \mathrm{C}_{6} \mathrm{H}_{5}\right)$.

$\mathbf{R M N}^{13} \mathbf{C}\left(\mathbf{C D C l}_{3}\right)$ (75.48 $\left.\left.\mathbf{M H z}\right): \square(\mathrm{ppm})=18.58 \mathrm{CH}\left(\mathrm{CH}_{3}\right)_{2}\right) ; 19.02$ $\left.\mathrm{C}\left(\mathrm{CH}_{3}\right)_{2}\right) ; 21.32,22.29$,

23.52, 24.75, 28.35, 28.44, 28.56, 31.22 et $31.57\left(\mathrm{CH}_{2}-\left(\mathrm{CH}_{2}\right)_{7}-\mathrm{CH}_{2}\right) ; 32.28$ $\left.\mathrm{CH}\left(\mathrm{CH}_{3}\right)_{2}\right) ; 32.38$

$\left.\mathrm{C}\left(\mathrm{CH}_{3}\right)_{2}\right) ; 36.71\left(\mathrm{CH}_{2}-\mathrm{CO}\right) ; 118.94(\mathrm{Co}) ; 123.07(\mathrm{Cp}) ; 127.84(\mathrm{Cm}) ; 137.14$ (Cipso); 170.98

(CO).

Synthesis of 9-methyl Hydroxyoctadecanoate 10-of Hydroxyoctadecanoate Methyl 15a and 15b

Few drops of sulfuric acid are added to a mixture of acid 9-and 10hydroxyoctadecanoic hydroxyoctadecanoic acid $(0.50 \mathrm{~g}, 1.67 \mathrm{mmol})$ in $4 \mathrm{ml}$ of methanol. The mixture is heated at $60^{\circ} \mathrm{C}$ for one hour. After then, it was heated under reflux for an hour. It is then neutralized with a diluted solution of $\mathrm{Na}_{2} \mathrm{CO}_{3}(1 \mathrm{ml}, 10 \%)$. The sentence Organic was extracted with pentane (5 $\mathrm{mL} \times 2$ ), and then it was dried over $\mathrm{Na}_{2} \mathrm{SO}_{4}$. After filtration, evaporation of the solvents leads to the production of $0.26 \mathrm{~g}$ of hydroxyesters $15 \mathrm{a}$ and $15 \mathrm{~b}$ $(50 \%)$.

IR: $\mathrm{n}(\mathrm{C}-\mathrm{O}-\mathrm{C})=1255 \mathrm{~cm}^{-1} ; \mathrm{n}(\mathrm{C}=\mathrm{O})=1740 \mathrm{~cm}^{-1} ; \mathrm{n}(\mathrm{O}-\mathrm{H})=3340 \mathrm{~cm}^{-1}$.

RMN ${ }^{1} \mathbf{H}\left(\mathbf{C D C l}_{3}\right)(\mathbf{3 0 0 . 1 3} \mathbf{M H z}): \square(\mathrm{ppm})=0.82\left(\mathrm{t},{ }^{3} \mathrm{JHH}=6.0 \mathrm{~Hz}, 3 \mathrm{H}\right.$, $\left.\mathrm{CH}_{3}\right) ; 1.36-1.21(\mathrm{~m}$,

$26 \mathrm{H},\left(\mathrm{CH}_{2}\right)_{7}-\mathrm{CHOH}-\left(\mathrm{CH}_{2}\right)_{6}$ et $\left.\left.\left(\mathrm{CH}_{2}\right)_{8}-\mathrm{CHOH}-\left(\mathrm{CH}_{2}\right)_{5}\right)\right) ; 1.54\left(\mathrm{~m}, 2 \mathrm{H}, \mathrm{CH}_{2}-\right.$ $\left.\mathrm{CH}_{2}-\mathrm{CO}\right) ; 2.24$ (t,

$\left.{ }^{3} \mathrm{JHH}=7.4,2 \mathrm{H}, \mathrm{CH}_{2}-\mathrm{CO}\right) ; 3.51(\mathrm{~m}, 1 \mathrm{H}, \mathrm{CH}-\mathrm{OH}) ; 3.60,3.61\left(\mathrm{~s}, 3 \mathrm{H}, \mathrm{OCH}_{3}\right)$.

$\mathbf{R M N}^{13} \mathbf{C}\left(\mathbf{C D C l}_{3}\right)$ (75.48 MHz): $\square(\mathrm{ppm})=14.10\left(\mathrm{CH}_{3}\right) ; 22.67\left(\mathrm{CH}_{2}-\mathrm{CH}_{3}\right)$; 24.91, 24.93

$\left(\mathrm{CH}_{2}-\mathrm{CH}_{2}-\mathrm{CO}\right) ; 25.56,25.61,25.66\left(\mathrm{CH}_{2}-\mathrm{CH}_{2}-\mathrm{CH}-\mathrm{OH}-\mathrm{CH}_{2}-\mathrm{CH}_{2}\right) ; 29.07$, 29.11, 29.18,

$29.21,29.28,29.32,29.39,29.47,29.57,29.61,29.64,29.71\left(\left(\mathrm{CH}_{2}\right)_{3}-\mathrm{CH}_{2-}\right.$ $\mathrm{CH}_{2}-\mathrm{CHOH}-\mathrm{CH}_{2}-$

$\mathrm{CH}_{2}-\left(\mathrm{CH}_{2}\right)_{4} ; 31.89\left(\mathrm{CH}_{2}-\mathrm{CH}_{2}-\mathrm{CH}_{3}\right) ; 34.08,34.10\left(\mathrm{CH}_{2}-\mathrm{CO}\right) ; 37.43,37.46$, $37.52\left(\mathrm{CH}_{2}-\mathrm{CHOH}\right)$;

$51.44\left(\mathrm{OCH}_{3}\right) ; 71.97,72.00(\mathrm{CH}-\mathrm{OH}) ; 174.30(\mathrm{CO})$.

Masse: (IE, $70 \mathrm{eV}) \mathbf{m} / \mathbf{z}=[\mathrm{M}-1]^{+}=313(1 \%)$; $\left[\mathrm{HO}=\mathrm{CH}-\left(\mathrm{CH}_{2}\right)_{7}-\mathrm{COOCH}_{3}\right]^{+}$ $=187(6 \%)$;

$\left[\mathrm{HO}=\mathrm{CH}-\left(\mathrm{CH}_{2}\right)_{8}-\mathrm{COOCH}_{3}\right]^{+}=201(5 \%)$. 


\section{Methyl Oleate by the Hydroboration of BBN}

A solution of methyl oleate $(0.80 \mathrm{~g}, 2.70 \mathrm{mmol})$ in $3 \mathrm{ml}$ of THF was added drop wise to BBN $(5.60 \mathrm{ml}, 2.80 \mathrm{mmol})$ in solution in THF $(0.5 \mathrm{M})$. The mixture is stirred for four hours at room temperature. NMR analysis proton of the reaction mixture shows that the reaction is not complete. The mixture is then refluxed for five hours. Concentration of the solvent under reduced pressure leads to the obtaining of a viscous liquid. In addition, the analysis of the mixture reaction by proton NMR shows the formation of $50 \%$ of hydro borate compounds.

IR: $\mathrm{n}(\mathrm{C}=\mathrm{O})=1743 \mathrm{~cm}^{-1}$.

RMN ${ }^{1} \mathbf{H}\left(\mathbf{C D C l}_{3}\right)$ (300.13 MHz): $\square(\mathrm{ppm})=0.83\left(\mathrm{t},{ }^{3} \mathrm{JHH}=6.7 \mathrm{~Hz}, 3 \mathrm{H}\right.$, $\left.\mathrm{CH}_{3}\right) ; 1.20$ (s.1, 26H, $\left(\mathrm{CH}_{2}\right)_{7}-\mathrm{CH}-\left(\mathrm{CH}_{2}\right)_{6}$ et $\left.\left.\left(\mathrm{CH}_{2}\right)_{8}-\mathrm{CH}-\left(\mathrm{CH}_{2}\right)_{5}\right)\right) ; 1.55$ (m, $\left.2 \mathrm{H}, \mathrm{CH}_{2}-\mathrm{CH}_{2}-\mathrm{CO}\right) ; 1.76$ $(\mathrm{m}, 14 \mathrm{H}$,

$(\mathrm{BBN})) ; 2.24\left(\mathrm{t},{ }^{3} \mathrm{JHH}=7.4 \mathrm{~Hz}, 2 \mathrm{H}, \mathrm{CH}_{2}-\mathrm{CO}\right) ; 3.60\left(\mathrm{~s}, 3 \mathrm{H}, \mathrm{OCH}_{3}\right)$.

\section{Synthesis of Compounds 16a, 16b, 16c, and 16d}

A solution of methyl linoleate $(0.75 \mathrm{~g}, 2.55 \mathrm{mmol})$ in $4 \mathrm{ml}$ of THF was added drop wise to BMS $(2.55 \mathrm{ml}, 5.10 \mathrm{mmol})$ dissolved in THF (2 M). The mixture is stirred for four hours at room temperature. After evaporation, we obtained $0.73 \mathrm{~g}$ of the compounds $(89 \%)$.

IR: $\mathrm{n}(\mathrm{C}=\mathrm{O})=1740 \mathrm{~cm}^{-1}$.

RMN ${ }^{1} \mathrm{H}\left(\mathbf{C D C l}_{3}\right)$ (300.13 MHz): $\square(\mathrm{ppm})=0.82\left(\mathrm{t},{ }^{3} \mathrm{JHH}=6.0 \mathrm{~Hz}, 3 \mathrm{H}\right.$, $\left.\mathrm{CH}_{3}\right) ; 1.23$ (s.1, 26H,

$\left(\mathrm{CH}_{2}\right)_{5}-\mathrm{CH}\left(\mathrm{BH}_{2}\right)-\mathrm{CH}_{2}-\mathrm{CH}\left(\mathrm{BH}_{2}\right)-\left(\mathrm{CH}_{2}\right)_{6} \quad$ et $\quad\left(\mathrm{CH}_{2}\right)_{5}-\mathrm{CH}\left(\mathrm{BH}_{2}\right)-\left(\mathrm{CH}_{2}\right)_{2}-$ $\left.\mathrm{CH}\left(\mathrm{BH}_{2}\right)-\left(\mathrm{CH}_{2}\right)_{5}\right) ; 1.56$

$\left(\mathrm{m}, 2 \mathrm{H}, \mathrm{CH}_{2}-\mathrm{CH}_{2}-\mathrm{CO}\right) ; 2.25\left(\mathrm{t},{ }^{3} \mathrm{JHH}=7.4,2 \mathrm{H}, \mathrm{CH}_{2}-\mathrm{CO}\right) ; 3.61\left(\mathrm{~s}, 3 \mathrm{H}, \mathrm{OCH}_{3}\right)$. $\mathbf{R M N}^{13} \mathbf{C}\left(\mathbf{C D C l}_{3}\right)$ (75.48 MHz): $\square(\mathrm{ppm})=14.07\left(\mathrm{CH}_{3}\right) ; 18.81,18.90,22.67$, 24.93, 25.67 et

$29.14\left(\mathrm{CH}_{2}\right)_{5}-\mathrm{CH}\left(\mathrm{BH}_{2}\right)-\mathrm{CH}_{2}-\mathrm{CH}\left(\mathrm{BH}_{2}\right)-\left(\mathrm{CH}_{2}\right)_{6}$ et $\left(\mathrm{CH}_{2}\right)_{5}-\mathrm{CH}\left(\mathrm{BH}_{2}\right)-\left(\mathrm{CH}_{2}\right)_{2}-$ $\left.\mathrm{CH}\left(\mathrm{BH}_{2}\right)-\left(\mathrm{CH}_{2}\right)_{5}\right)$;

$31.89\left(\mathrm{CH}_{2}-\mathrm{CH}_{2}-\mathrm{CO}\right) ; 34.05\left(\mathrm{CH}_{2}-\mathrm{CO}\right) ; 51.37\left(\mathrm{OCH}_{3}\right) ; 174.26(\mathrm{CO})$.

\section{Synthesis of Dihydroxyoctadecanoïques Acids 17a, 17b, 17c, 17d}

According to the strong oxidation procedure, $1 \mathrm{ml}$ of $\mathrm{HCl}(5 \%)$ was added to a solution of organoboranes: 16a, 16b, 16c, and $16 \mathrm{~d}(0.50 \mathrm{~g}, 1.55$ $\mathrm{mmol}$ ) in $4 \mathrm{ml}$ of acetone. The solvent was concentrated in vacuum, while the residue was then dissolved in $5 \mathrm{ml}$ of THF. The resulting solution is alkalinized by $9.20 \mathrm{ml} \mathrm{NaOH} \mathrm{(40 \% )} \mathrm{and} \mathrm{treated} \mathrm{slowly} \mathrm{with} 14.00 \mathrm{ml}$ of a solution of $30 \% \mathrm{H}_{2} \mathrm{O}_{2}$. The mixture is then heated for three hours. After cooling, the reaction mixture is acidified with a $35 \% \mathrm{HCl}$ solution. The organic phase was collected and the aqueous phase is extracted with chloroform. The 
organic phases are dried on sodium sulfate. After evaporation, we obtained $0.40 \mathrm{~g}$ of a white solid $(78 \%)$.

IR: $\mathrm{n}(\mathrm{C}=\mathrm{O})=1699 \mathrm{~cm}^{-1} ; \mathrm{n}(\mathrm{O}-\mathrm{H})=3424 \mathrm{~cm}^{-1}$.

RMN ${ }^{1} \mathbf{H}(\mathbf{C D C l})$ (300.13 MHz): $\square(\mathrm{ppm})=0.83(\mathrm{t}, 3 \mathrm{JHH}=6.0 \mathrm{~Hz}, 3 \mathrm{H}$, $\left.\mathrm{CH}_{3}\right) ; 1.24$ (s.1, 26H,

$\left(\mathrm{CH}_{2}\right)_{5}-\mathrm{CH}(\mathrm{OH})-\mathrm{CH}_{2}-\mathrm{CH}(\mathrm{OH})-\left(\mathrm{CH}_{2}\right)_{6}$ et $\left(\mathrm{CH}_{2}\right)_{5}-\mathrm{CH}(\mathrm{OH})-\left(\mathrm{CH}_{2}\right)_{2}-\mathrm{CH}(\mathrm{OH})-$ $\left.\left(\mathrm{CH}_{2}\right)_{5}\right) ; 1.56(\mathrm{~m}$,

$\left.2 \mathrm{H}, \mathrm{CH}_{2}-\mathrm{CH}_{2}-\mathrm{CO}\right) ; 2.28$ (t, $\left.{ }^{3} \mathrm{JHH}=7.4,2 \mathrm{H}, \mathrm{CH}_{2}-\mathrm{CO}\right) ; 3.61(\mathrm{~m}, 2 \mathrm{H}, \mathrm{CH}-\mathrm{OH})$.

$\mathbf{R M N}^{13} \mathbf{C}(\mathbf{C D C l} 3)$ (75.48 MHz): $\square(\mathrm{ppm})=14.13\left(\mathrm{CH}_{3}\right) ; 22.66,24.73,25.52$, 29.09, 29.20,

$29.33,29.38,29.49,29.62,29.68,29.73,31.88\left(\mathrm{CH}_{2}\right)_{5}-\mathrm{CH}(\mathrm{OH})-\mathrm{CH}_{2}-$ $\mathrm{CH}(\mathrm{OH})-\left(\mathrm{CH}_{2}\right)_{6}$ et

$\left.\left(\mathrm{CH}_{2}\right)_{5}-\mathrm{CH}(\mathrm{OH})-\left(\mathrm{CH}_{2}\right)_{2}-\mathrm{CH}(\mathrm{OH})-\left(\mathrm{CH}_{2}\right)_{5}\right) ; 34.09\left(\mathrm{CH}_{2}-\mathrm{CO}\right) ; 37.32\left(\mathrm{CH}_{2}-\mathrm{CH}-\right.$ $\mathrm{OH}) ; 71.90$,

71.99, 72.14, 72.40, 72.49 (CH-OH); 178.82, 178.88, 178.99 (CO).

Masse: (IE, $70 \mathrm{eV}) \mathbf{m} / \mathbf{z}=[\mathrm{M}+1]^{+}=317(1 \%) ;\left[\mathrm{HO}=\mathrm{CH}-\left(\mathrm{CH}_{2}\right)_{2}-\right.$ $\left.\mathrm{CH}(\mathrm{OH})\left(\mathrm{CH}_{2}\right)_{8}-\mathrm{COOH}\right]^{+}=$

$\left[\mathrm{HO}=\mathrm{CH}-\left(\mathrm{CH}_{2}\right)_{3}-\mathrm{CH}(\mathrm{OH})\left(\mathrm{CH}_{2}\right)_{7}-\mathrm{COOH}\right]^{+}=245(2 \%) ; \quad\left[\mathrm{HO}=\mathrm{CH}-\left(\mathrm{CH}_{2}\right)_{2}{ }_{2}\right.$ $\left.\mathrm{CH}(\mathrm{OH})\left(\mathrm{CH}_{2}\right)_{7}-\mathrm{COOH}\right]^{+}=\left[\mathrm{HO}=\mathrm{CH}-\mathrm{CH}_{2}-\mathrm{CH}(\mathrm{OH})\left(\mathrm{CH}_{2}\right)_{8}-\mathrm{COOH}\right]^{+}=231$ $(3 \%) ;\left[\mathrm{HC}=\mathrm{CH}-\mathrm{CH}_{2}-\right.$

$\left.\mathrm{CH}(\mathrm{OH})\left(\mathrm{CH}_{2}\right)_{8}-\mathrm{COOH}\right]^{+}=\left[\mathrm{HC}=\mathrm{CH}-\left(\mathrm{CH}_{2}\right)_{2} \mathrm{CH}(\mathrm{OH})\left(\mathrm{CH}_{2}\right)_{7}-\mathrm{COOH}\right]^{+}=227$ $(13 \%)$;

$\left[\mathrm{HC}=\mathrm{CH}-\mathrm{CH}_{2}-\mathrm{CH}(\mathrm{OH})\left(\mathrm{CH}_{2}\right)_{7}-\mathrm{COOH}\right]^{+} \quad=\quad\left[\mathrm{HC}=\mathrm{CH}-\mathrm{CH}(\mathrm{OH})\left(\mathrm{CH}_{2}\right)_{8}{ }^{-}\right.$ $\mathrm{COOH}]^{+}=213(18 \%)$;

$\left[\mathrm{CH}_{3}-\left(\mathrm{CH}_{2}\right)_{5}-\mathrm{CH}(\mathrm{OH})-\mathrm{CH}_{2}-\mathrm{CH}=\mathrm{OH}\right]^{+}=\left[\mathrm{CH}_{3}-\left(\mathrm{CH}_{2}\right)_{4}-\mathrm{CH}(\mathrm{OH})-\left(\mathrm{CH}_{2}\right)_{2}-\right.$ $\mathrm{CH}=\mathrm{OH}]+=159$

$(14 \%) ; \quad\left[\mathrm{CH}_{3}-\left(\mathrm{CH}_{2}\right)_{5}-\mathrm{CH}(\mathrm{OH})-\mathrm{CH}=\mathrm{CH}\right]^{+}=\left[\mathrm{CH}_{3}-\left(\mathrm{CH}_{2}\right)_{4}-\mathrm{CH}(\mathrm{OH})-\mathrm{CH}_{2}-\right.$ $\mathrm{CH}=\mathrm{CH}]^{+}=141$

$(37 \%)$.

\section{Synthesis of Dihydroxyoctadecanoats of Methyl 18a, 18b, 18c and 18d}

Few drops of sulfuric acid are added to the acid mixture of dihydroxyoctadecanoïque $17 \mathrm{a}, 17 \mathrm{~b}, 17 \mathrm{c}$ and $17 \mathrm{~d}(1.00 \mathrm{~g}, 3.16 \mathrm{mmol})$ in $10 \mathrm{ml}$ of methanol. The mixture is heated at $60^{\circ} \mathrm{C}$ for one hour, and then refluxed for two hours. It is then neutralized with a diluted solution of $\mathrm{Na}_{2} \mathrm{CO}_{3}(2 \mathrm{ml}$, $10 \%)$. The organic phase is extracted with pentane $(10 \mathrm{ml} \times 2)$, and then dried over $\mathrm{Na}_{2} \mathrm{SO}_{4}$. After filtration and evaporation, we obtained $0.52 \mathrm{~g}$ of a white gel $(50 \%)$.

IR: $\mathrm{n}(\mathrm{C}=\mathrm{O})=1740 \mathrm{~cm}^{-1} ; \mathrm{n}(\mathrm{O}-\mathrm{H})=3424 \mathrm{~cm}^{-1}$.

RMN ${ }^{1} \mathbf{H}\left(\mathbf{C D C l}_{3}\right)(\mathbf{3 0 0 . 1 3} \mathbf{M H z}): \square(\mathrm{ppm})=0.83\left(\mathrm{t},{ }^{3} \mathrm{JHH}=6.0 \mathrm{~Hz}, 3 \mathrm{H}\right.$, $\left.\mathrm{CH}_{3}\right) ; 1.24$ (s.1, 26H, 
$\left(\mathrm{CH}_{2}\right)_{5}-\mathrm{CH}(\mathrm{OH})-\mathrm{CH}_{2}-\mathrm{CH}(\mathrm{OH})-\left(\mathrm{CH}_{2}\right)_{6}$ et $\left(\mathrm{CH}_{2}\right)_{5}-\mathrm{CH}(\mathrm{OH})-\left(\mathrm{CH}_{2}\right)_{2}-\mathrm{CH}(\mathrm{OH})-$ $\left.\left(\mathrm{CH}_{2}\right)_{5}\right) ; 1.56(\mathrm{~m}$,

$\left.2 \mathrm{H}, \mathrm{CH}_{2}-\mathrm{CH}_{2}-\mathrm{CO}\right) ; 2.25$ (t, $\left.{ }^{3} \mathrm{JHH}=7.4,2 \mathrm{H}, \mathrm{CH}_{2}-\mathrm{CO}\right) ; 3.40-3.61$ (m, 2H, CH$\mathrm{OH}) ; 3.61(\mathrm{~s}$,

$\left.3 \mathrm{H}, \mathrm{OCH}_{3}\right)$.

$\mathbf{R M N}^{13} \mathbf{C}(\mathbf{C D C l})$ (75.48 MHz): $\square(\mathrm{ppm})=14.03,14.06\left(\mathrm{CH}_{3}\right) ; 22.32,22.60$, 22.65, 24.92,

$25.61,25.65,29.08,29.12,29.17,29.21,29.35,29.38,29.53,29.56,29.59$, 29.68, 31.82,

$31.88,\left(\mathrm{CH}_{2}\right)_{5}-\mathrm{CH}(\mathrm{OH})-\mathrm{CH}_{2}-\mathrm{CH}(\mathrm{OH})-\left(\mathrm{CH}_{2}\right)_{6}$ et $\left(\mathrm{CH}_{2}\right)_{5}-\mathrm{CH}(\mathrm{OH})-\left(\mathrm{CH}_{2}\right)_{2}-$ $\left.\mathrm{CH}(\mathrm{OH})-\left(\mathrm{CH}_{2}\right)_{5}\right)$;

$34.07\left(\mathrm{CH}_{2}-\mathrm{CO}\right) ; 37.49,37.44\left(\mathrm{CH}_{2}-\mathrm{CH}-\mathrm{OH}\right) ; 51.41\left(\mathrm{OCH}_{3}\right), 71.89,71.97$, $72.23,72.28$,

(CH-OH); $174.30(\mathrm{CO})$.

Masse: (IE, $70 \mathrm{eV}) \mathbf{m} / \mathbf{z}=[\mathrm{M}+1]^{+}=331(1 \%) ;[\mathrm{M}-\mathrm{OH}]^{+}=313(3 \%)$; $\left[\mathrm{HO}=\mathrm{CH}-\left(\mathrm{CH}_{2}\right)_{2}-\right.$

$\left.\mathrm{CH}(\mathrm{OH})\left(\mathrm{CH}_{2}\right)_{8}-\mathrm{COOCH}_{3}\right]^{+}=\left[\mathrm{HO}=\mathrm{CH}-\left(\mathrm{CH}_{2}\right)_{3}-\mathrm{CH}(\mathrm{OH})\left(\mathrm{CH}_{2}\right)_{7}-\mathrm{COOCH}_{3}\right]^{+}$ $=259(1 \%)$;

$\left[\mathrm{HO}=\mathrm{CH}-\left(\mathrm{CH}_{2}\right)_{2}-\mathrm{CH}(\mathrm{OH})\left(\mathrm{CH}_{2}\right)_{7}-\mathrm{COOCH}_{3}\right]_{+} \quad=\quad\left[\mathrm{HO}=\mathrm{CH}-\mathrm{CH}_{2}-\right.$ $\left.\mathrm{CH}(\mathrm{OH})\left(\mathrm{CH}_{2}\right){ }_{8}-\mathrm{COOCH}_{3}\right]^{+}=$

245 (4\%); $\left[\mathrm{CH}=\mathrm{CH}-\mathrm{CH}_{2}-\mathrm{CH}(\mathrm{OH})\left(\mathrm{CH}_{2}\right)_{8}-\mathrm{COOCH}_{3}\right]^{+}=\left[\mathrm{CH}=\mathrm{CH}-\left(\mathrm{CH}_{2}\right)_{2}-\right.$ $\mathrm{CH}(\mathrm{OH})\left(\mathrm{CH}_{2}\right)_{7-}$

$\left.\mathrm{COOCH}_{3}\right]^{+}=241(2 \%) ; \quad\left[\mathrm{HC}=\mathrm{CH}-\mathrm{CH}_{2}-\mathrm{CH}(\mathrm{OH})\left(\mathrm{CH}_{2}\right)_{7}-\mathrm{COOCH}_{3}\right]^{+}=$ $\left[\mathrm{HC}=\mathrm{CHCH}(\mathrm{OH})\left(\mathrm{CH}_{2}\right)_{8}-\mathrm{COOCH}_{3}\right]^{+}=227(5 \%)$.

\section{Acknowledgement}

This work was supported by the Central Administration of the Lebanese University.

\section{References:}

1. Allinger N. L., Cava M. P., De Jongh D. C., Johnson C. R., Lebel N. A., \& Stevens C. L. (1983). "chimie organique", vol.2, 343-345.

2. Brown H. C. \& Zweifel G. (1960). J. Am. Chem. Soc., 82, 4708.

3. Brown H. C. \& Sharp R. L. (1968). J. Am. Chem. Soc., 90, 2915.

4. Brown H. C., Knights E. F., \& Scouten C. G (1974). J. Am. Chem. Soc., 96, 7765.

5. Brown H. C. \& Keblys K. A. (1964). J. Am. Chem. Soc., 86, 1795.

6. Brown H. C. \& Klender G. J. (1962). Inorg. Chem., 1, 204.

7. Brown H. C., Rothberg I., \& Vanderjact D. L. (1972). J. Org. Chem., 37, 4098. 
8. Brown H. C, Zaid leurcz M., Negishi E. , "COMC-I", vol.7, 111; 161; 229; 270; 305; 326; 354; 254.

9. Fore P. \& Bickford W. G. (1959). J. Org. Chem., 24, 920.

10. Ghebreyessus K. Y. \& Angelici R. J. (2006). Organometallique, 25, 3040.

11. Kabalka G. W. \& Bierer D. E. (1989). Organometallique, 1989, 8, 655.

12. Lane C. F. (1976). Chemical Reviews, vol 76, №6, 773.

13. Matteson D. S. (1987). Dans "the chemistry of the Metal-Carbon Bond", ed. F. R. Hartley, Wiley, New York, vol.4, p. 307; 330; 346; $350 ; 351 ; 353 ; 357 ; 368$.

14. Peliter A. \& Smith K. dans (1979). "Compehensive Organic Chemistry" ed. D. N. Jones, Pergamon Press, p 695.

15. Smith dans K. (1994). "Organometallics in synthesis - A Manual" ed. M. Schlosser, John Wiley,Sons Ltd, p 461.

16. Tulloch A. P. (1966). J. Am. Oil. Chem. Soc., 43, 670.

17. Thiemt S. \& Spiteller G. (1997). In. J. Mass. Spec. Ion. Pro., 160, 269.

18. Vig O. P., Trehan I.R., Kad G.L., Dhawan R.K. \& Grewal (1980). M.S., Indian. J. Chem. Sect. B., 19B, 688.

19. Yoon N. M., Pak C., Brown H. C., Krishnamurthy S., \& Stocky T. P. (1973). J. Org. Chem,38, 2786. 